\title{
TRANSITION INTO THE WORKFORCE: ECONOMIC INTEGRATION OF FORMER GOVERNMENT ASSISTED REFUGEES AND FORMER REFUGEE CLAIMANTS
}

By

Hila Taraky, BA. McMaster University, 2010

\author{
In partial fulfillment of the requirements for the degree of \\ Master of Arts \\ in the Program of \\ Immigration and Settlement Studies
}

Toronto, Ontario, Canada, 2011

Hila Taraky 2011 


\section{AUTHOR'S DECLARATION}

I hereby declare that I am the sole author of this Major Research Paper.

I authorize Ryerson University to lend this paper to other institutions or individuals for the purpose of scholarly research.

Sig

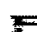

I further authorize Ryerson University to reproduce this paper by photocopying or by other means, in total, or in part, at the request of other institutions or individuals for the purpose of scholarly research.

Signatv 


\title{
TRANSITION INTO THE WORKFORCE: ECONOMIC INTEGRATION OF FORMER GOVERNMENT ASSISTED REFUGEES AND FORMER REFUGEE CLAIMANTS
}

\author{
By: Hila Taraky \\ Master of Arts, 2011 \\ Immigration and Settlement Studies \\ Ryerson University
}

\begin{abstract}
While research in the sphere of settlement and integration is wide in scope and subject, it largely focuses on the labour market outcomes and economic integration of skilled immigrants. Such research exemptions do not capture the economic integration of other immigrant classes such as refugees. In light of such research gaps, this study aimed to examine the economic integration of former Government Assisted Refugees (GARs) and former refugee claimants in Hamilton, Ontario. Through a series of four interviews with former GARs and former refugee claimants who are working within Hamilton's social service sector, this study found that the experiences of refugees can be captured by a combination of human capital and social capital frameworks. Similar to skilled immigrants, refugees are better able to transition into professional fields upon enrolling in post-secondary educational institutions, volunteering, and networking with members outside of their own ethno-cultural community. This study also found that immediate settlement supports, offered by the Resettlement Assistance Program, had positive long term affects on the economic integration of GARs. Former refugee claimants did not have such immediate services and as a result had frustrating immediate settlement experiences. It is therefore argued that the RAP mitigates many systematic and structural barriers which otherwise pose as barriers for the economic integration of refugees.
\end{abstract}

\section{Key words:}

Labour market outcomes; refugees; immigrants; employment; Government Assisted Refugees 


\section{Acknowledgements}

First and foremost, I would like to thank Dr. Myer Siemiatycki for his guidance, support, and encouragement. Professor Siemiatycki has mentored me throughout the conceptual and technical aspects of this research project. His attention to detail, invaluable expertise, and supportive persona have empowered me as a graduate student and a researcher.

I would like to express my gratitude to Dr. Anver Saloojee for acting as the second reader for this project and providing me with his valuable feedback and suggestions. A sincere thanks also goes out to Dr. Doreen Fumia for broadening my academic experience, sharing her insight, and challenging my understanding of the world.

I am grateful to the research participants for sharing with me their time, their insight and experiences. This research project would not have been possible without the informant's expertise.

I would like to thank my parents, Marufa Shinwari and Yar Taraky; siblings, Tahmina and Abdullah; and grandparents, Sayed Rahman Shinwary and Rahima Shinwary for cheering me on throughout this research project. My family has played a pivotal role in strengthening the conceptual framework of this project by challenging and critiquing my research. I love each of them dearly and am blessed to have such a support system.

Last but certainly not least, I would like to thank Maaz Mahmood for his reassurance, for encouraging my academic endeavors, and for provoking my curiosity. Truly, Maaz played a pivotal role in the development and completion of this MRP.

This research project could not have been possible without the contributions of aforementioned people. 


\section{CONTENTS}

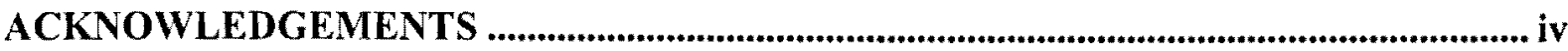

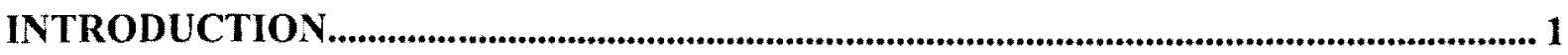

GOVERNMENT ASSISTED REFUGEES (GARS) AND THE RESETTLEMENT

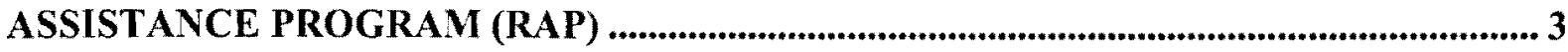

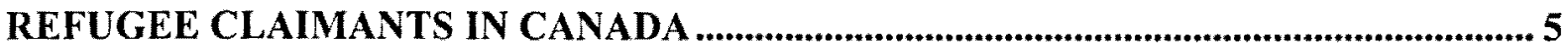

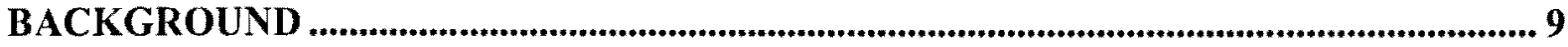

SETTLEMENT OF GOVERNMENT ASSISTED REFUGEES ……....................................... 10

EVALUATIONS OF THE RESETTLEMENT ASSISTANCE PROGRAM ..................................... 15

ECONOMIC INTEGRATION OF FORMER REFUGEE CLAIMANTS ..................................... 16

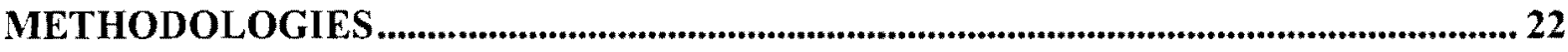

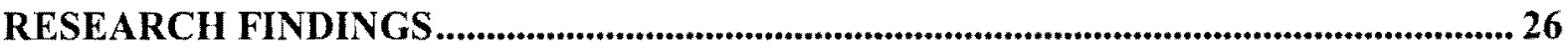

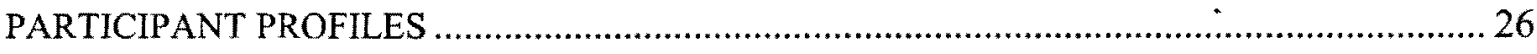

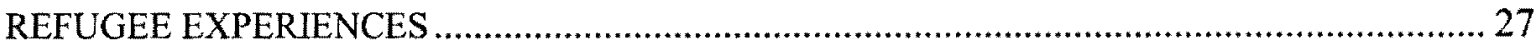

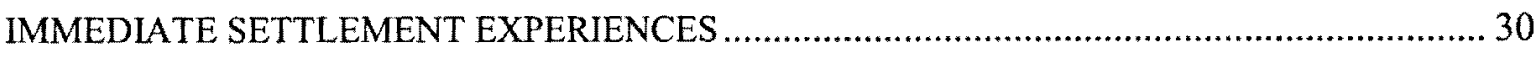

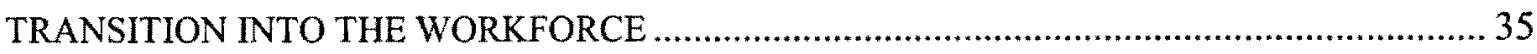

WORKING WITH OTHER NEWCOMERS AND SUGGESTED CHANGES................................ 43

DISCUSSION ...................................................................................................................................... 50

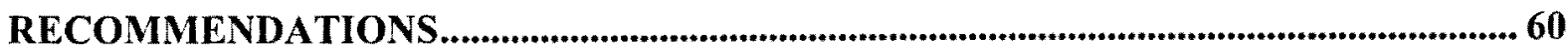

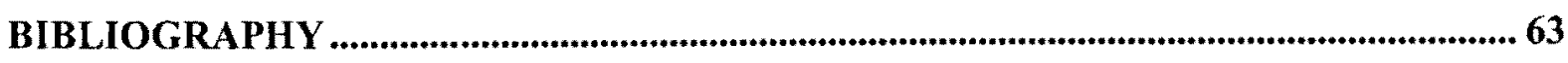




\section{Introduction}

Scholars and politicians alike have carried out extensive research to examine the labour market outcomes of skilled immigrants. Such research has found that a severe gap exists in the earnings and labour market outcomes of skilled immigrants compared to Canadian born individuals (Ferrer \& Riddell, 2008; see also Wald \& Fang, 2008; Reitz, 2005; Oreopoulos, 2009; Mata, 2008; Hiebert, 2009; Girard, Smith \& McGill, 2010). Contemporary research has predominantly employed the use of human capital, social capital and social structural frameworks to explain poor labour market outcomes and earnings disparities between skilled immigrants and native born Canadians (Ferrer \& Riddell, 2008; see also Wald \& Fang, 2008; Reitz, 2005; Oreopoulos, 2009; Mata, 2008; Hiebert, 2009; Girard, Smith \& McGill, 2010; Dietz, Esses, Joshi \& AbuAyyash, 2009). Social structural frameworks examine the ways in which social structures "limit the value of immigrant educational credentials... and [argue that] labour markets are never neutral and the value of an individual's credential are distorted by gender, social class, race, and nativity" (Trache \& Sweet, 2005, p. 181). Meanwhile, human capital theories suggest that further schooling will ensure greater labour market integration and increased economic returns for newcomers (Ferrer \& Riddell, 2008). Where, human capital focuses on economic rewards of education and training, social capital highlights the role of weak-and-strong social ties, social networks, and connections on capital accumulation (Matthews, Pendakur \& Young, 2009).

While research in the sphere of settlement and integration is wide in scope and subject, it largely focuses on the labour market outcomes and economic integration of skilled immigrants. Such research exemptions do not capture the economic integration of other immigrant classes such as refugees. In light of such research gaps, this study aimed to examine the economic 
integration of former Government Assisted Refugees (GARs) and former refugee claimants in Hamilton, Ontario. More specifically, this research project intended to investigate the tools which were used by former GARs and former refugee claimants to transition into the Canadian workforce. Furthermore, this research project aimed to examine the short term and long term effects of the Resettlement Assistance Program (RAP) on the settlement of GARs. Through a series of interviews with former GARs and former refugee claimants, this study aims to determine if human capital and social capital frameworks can be used to understand the transition of refugees into professional occupations. The following research questions were used to guide research objectives:

1. What were the tools used by former GARs and former refugee claimants to transition into the Canadian labour force?

2. What impact, if any, did RAP have on the economic integration of former GARs in Canada? 


\section{Government Assisted Refugees (GARs) and the Resettlement Assistance Program (RAP)}

Government Assisted Refugees, hereafter GARs, are selected through a United Nations High Commission for Refugees (UNHCR) referral process. GARs are sponsored by the federal government of Canada or through private sponsorship, and are classified as the Convention Refugees Abroad Class or the Source Country Class (Navaratna, 2006; see also Debeljacki, 2007; Murdie; 2008; Presse \& Thomson, 2008). The Convention Refugees Abroad Class refers to refugees who are under the protection of the UNHCR, outside of their country of origin (CIC, 2010; see also CIC, 2011). In the later case, Source Country Class refers to refugees who are residing in their country of origin and meet UNHCR's designation of a Convention Refugee (CIC, 2010; see also CIC, 2011). Currently, there are approximately 10.4 million refugees under the protection of UNHCR (UNHCR, 2010). This number does not include internationally displaced persons, nor refugees who fall under the United Nations Relief and Works Agency mandate (UNHCR, 2010).

Annually, the Minister of Citizenship, Immigration and Multiculturalism decides “...the number of refugees to be brought to Canada...under the Government-Assisted Refugee (GAR) Program" (CIC, 2011, pp. 5). As of 2002, GARs' settlement and integration to life in Canada is the responsibility of the Resettlement Assistance Program, hereafter (RAP). While financial support and assistance is administered by local CIC officer, RAP is responsible for the provision of 'immediate and essential' services (CIC, 2011, pp. 6). "RAP services are generally received within the first 4 to 6 weeks of GARs' arrival in Canada..." and include the administration of services such as needs assessments, orientation sessions, referrals to federal and provincial settlement programs, temporary accommodation and assistance with permanent accommodation, 
reception services and more (CIC, 2011, pp. 6). GARs are supported by the RAP centres across Canada; they receive income support for twelve (12) to twenty four (24) months, and RAP

...[is] responsible for welcoming GARs at ports of entry, providing temporary accommodation, assessing entitlements and needs, conducting orientation sessions (to ensure that GARs understand their income support entitiements, rights and responsibilities etc.), providing help with finding permanent accommodation, assessing clients for their needs and making referrals to other community organizations as necessary (Navaratna, 2006, pp. 11).

Currently, the RAP operates in 23 communities across Canada (CIC, 2011). The RAP's staff often have the burden of responsibility to provide RAP and non-RAP services to GARs. Furthermore, CIC has found that "...the total number of hours provided to GARs for all the orientation services, excluding orientation to federal and provincial programs, has increased since 2005" (CIC, 2011, pp. 28).

While the RAP provides essential and immediate settlement services for GARs, it is important to note that GARs arrive in Canada after undergoing violent and traumatic experiences of war, torture, and persecution. Furthermore, many GARs have endured living in refugee camps where basic and essential human needs are not met. Many GAR families arrive with children and youth who have never attended formal schooling. Nevertheless, there are GARs resettled in Canada who do immigrate with high levels of human capital and whose professional careers have been halted due to civil war, political unrest, or persecution. It is therefore imperative to study the enabling factors which contribute to the entrance of former GARs into regulated professions in Canada. 


\title{
Refugee Claimants in Canada
}

The government of Canada grants asylum to approximately 25, 000 Convention Refugees through the domestic refugee protection-asylum system and the Refugee and Humanitarian Resettlement Program (DeVoretz et al., 2004; see also Murdie, 2008; Simich, 2003; Krahn, 2000; Presse \& Thomson, 2008). As per the 1951 United Nations Convention on the Status of Refugees, a Convention Refugee is a person who

\begin{abstract}
...owing to a well founded fear of being persecuted for reasons of race, religion, nationality, membership of a particular social group or political opinion, is outside the country of his nationality and is unable or, owing to such fear, unwilling to avail himself of the protection of that country; or who, not having a nationality and being outside the country of his former habitual residence as a result of such events, is unable, or owing to such fear, is unwilling to return to it. (UNHCR, 1950, pp. 46)
\end{abstract}

As a signatory to the Geneva Convention, Canada must uphold the rights of refugees within its constitutional and legislative frameworks. While Government Assisted Refugees gain Convention Refugee status from the United Nations High Commission for Refugees (UNHCR) outside of Canada's borders, the domestic asylum system is used for inland refugees who claim Convention Refugee status within Canada's borders. Refugee claimants therefore have a legal right under both international and Canadian law to make a claim in Canada.

Prior to the 1980 's, refugees made their claims on paper, without an opportunity for a court hearing (Lacroix, 2004). However, following the 1985 Singh case, the Supreme Court of Canada "...declared that claimants had a right to an oral hearing and that existing procedures violated the Charter of Rights and Freedoms" (Lacroix, 2004, pp. 150; see also CIC, 2002). In 1987, Bill C-55 and Bill C-84 aimed to streamline the refugee determination process (CIC, 2002; see also Lacroix, 2004; Jayasinghe, 2011; Dawson, 2011). Both pieces of legislation worked together to create the Immigration and Refugee Board (IRB) and granted immigration officers the power to fine ships, cargo trucks, and later plains for carrying refugees. In 2002, further 
changes were made to the Immigration and Refugee Protection Act which made the refugee claims heard by a single member of the IRB and eliminated the appeal process (Navaratna, 2006; see also Lacroix, 2004).

Refugee determination encompasses a set of highly bureaucratized processes which begin when refugees declare their intention to claim asylum in Canada. Upon making this declaration at a local CIC office, Canada must admit the individual or family to Canada while the claim is adjudicated (CIC, 2002; see also Lacroix, 2004). The claimants are provided with an application which must be completed and returned to the IRB within 28 days (CIC, 2002; see also Lacroix, 2004). Claimants who are found eligible are referred to the "...Refugee Protection Division (RPD) for a determination of their claim...Claimants are provided with a Personal Information Form to complete and send to the RPD outlining the basis of the claim" (CIC, 2002, The Refugee Hearing, Sec. A). The refugee claimant first waits for a hearing date from the IRB. Following the hearing, the claimant awaits for the decision. If approved, the refugee claimants are granted Convention Refugee status and may apply for permanent residency. A negative decision may result in deportation from the country or an appeal for humanitarian considerations in the case (CIC, 2002).

In 2007 , Canada provided protection to approximately 15,000 inland protected persons (CIC, 2007). This number was reduced to 7,000 in 2009 and 10,000 in 2010 (CIC, 2010). While GARs are supported by the services and advocacy of the Resettlement Assistance Program (RAP), refugee claimants are seen as asylum seekers who "...do not have access to the same level of settlement services" (Renaud et al. 2003, pp. 4). Refugee claimants have "...limited access to work, social welfare, health and social services and are generally separated from their immediate families" (Lacroix, 2004, pp. 152). "It takes refugee claimants at least three months to 
obtain a work permit and they must have a job offer before they are eligible for employment" (Renaud et al. 2003, pp. 4). Furthermore, refugees must wait for lengthy periods of time for their claims to be processed and are required to maneuver and adapt to the Canadian system independently.

It is also worth noting that while GARs are seen as 'good' law abiding refugees who wait for their turn to be resettled, inland refugee claimants are often depicted as illegal migrants. The criminalization of the refugee process distinctively differentiates between legal and illegal migration. Refugee claimants are often viewed with suspicion and undergo public scrutiny in Canada in both legal and social realms. The negative discourse associated with claiming refugee status within Canada's borders can be attributed to the process of being smuggled into the country. The Ministry of Public Safety Canada states that "...human smuggling undermines Canada's security. Large scale arrivals make it difficult to properly investigate whether those who arrive, including the smugglers themselves, pose risks to Canada on the basis of either criminality or national security" (Public Safety Canada, 2010, pp. 1) Such a rigid response to smuggling is not a new phenomenon in Canada's immigration history. Asylum seekers have often been framed in the context of health risks, risks to national security, and a drain on public resources. The 2010 changes to immigration policy further reflect Canada's position on refugees. Such legislative measures demonstrate the ways in which laws and policies systematically other refugees. Alison Mountz (2004) suggests that "...the response of the Canadian government to human smuggling illuminates inconsistencies regarding the global positioning of Canada as both humanitarian, refugee receiving nation and enforcer." (Mountz, 2004, Pp. 1) Meanwhile, the author correctly contends that the refugee is dehumanized and depersonalized as an individual in a contained crowd (Mountz, 2004, Pp. 5) 
Human smuggling is indeed a politically charged term which incidentally reinforces ideas of state hood, nationalism, and state sovereignty. Canada is not alone in producing the distinction between legitimate and illegitimate or undocumented migration by refugees. The United Nations Convention on Transnational Organized Crime produced protocols pertaining to human smuggling and human trafficking came into force in 2003 and 2004 (Bhabha, 2005, pp. 2). Human smuggling is defined in Article 2 of the Protocol Against the Smuggling of Migrants by Land, Sea and Air as "[The] smuggling of migrants shall mean the procurement, in order to obtain, directly or indirectly, a financial or other material benefit, of the illegal entry of a person into a state party of which the person is not a national or permanent resident" (Bilger et al., 2006, pp 2). Where, human trafficking is conceptualized as a coercive act which creates victims, human smuggling is described as a service provided for consenting clients (Bhabha, 2005).

The experiences of inland asylum seekers who later become refugee claimants in Canada can best be characterized as a time of crisis. Refugee claimants flee persecution and become “...confronted with a refugee determination system" (Lacroix, 2004, pp. 149).

Torn between humanitarian and economic, social, political and post-September 11 , security concerns, policies are primarily directed at reducing the number of asylum-seekers by any administrative means and many argue 'the logic of exclusion predominates' (Lacroix, 2004, pp. 149).

Both the former refugee claimants and former GARs interviewed for this research project, as will be shown later, identified with experiences of persecution, being smuggled across borders and undergoing refugee determination processes. While former GARs underwent the refugee determination process abroad, former refugee claimants waited for the same outcome in Canada. 


\section{Background}

After conducting a thorough review of the literature, this paper finds that research on the economic integration and labour market outcomes of both Government Assisted Refugees and refugee claimants is scarce. Where some research does address the economic integration of refugees, work on GARs tends to emphasize the broader settlement experiences of various GAR groups across Canada. It is important to note that the economic integration of the two groups, GARs and refugee claimants respectively, have not been compared by immigration researchers.

Previous studies conducted in the last ten years indicate that the labour market integration of GARs have not been the primary objectives of studies. Research projects often concentrated on other areas of GAR settlement such as language ability, social inclusion, or housing outcomes and briefly mentioned economic integration (Debeljacki, 2007; see also Murdie, 2008; SRDC, 2002; Simich et al. 2002; Yu et al. 2007). It is also evident that the bulk of research pertaining to GARs aimed at evaluating the effectiveness of the Resettlement Assistance Program in delivering settlement supports to GARs (Navaratna, 2006; see also SRDC, 2002; Power Analysis Inc, 2002; Presse \& Thomson, 2008). Consequently, scholarly work on GARs can be grouped into two broad areas of research; a) the settlement of GARs in the Canadian society and b) the evaluation of the Resettlement Assistance Program. Meanwhile, a review of the literature on the economic integration of non-GAR refugees reveals that researchers employ the use of similar theoretical frameworks to study the labour market outcomes of refugees as skilled immigrants. Scholarly works on the economic integration of refugees draw on human capital, social capital, and social structural frameworks to explain earnings disparities between refugees and Canadian born workers. As we will later see, this may be appropriate given that similar tools are used by 
both skilled refugees and the skilled immigrant class to transition into the Canadian labour market.

This section of the paper will first provide a thorough account of academic research which has addressed the settlement of GARs in Canada. Subsequently, this literature review will present an overview of research which evaluates the effectiveness of the RAP in providing resettlement services and supports to GARs. Finally, this section will discuss the limited, yet important body of research which has addressed the labour market integration of refugee claimants in Canada.

\section{Settlement of Government Assisted Refugees}

Although contemporary scholarship does not frequently distinguish between various refugee classes, some academics have begun to investigate the integration of GARs in Canada. This section will highlight key research findings which examine the role of social supports, housing outcomes and language acquisition on GARs' settlement and integration in Canada. While this section provides a thorough background, it is evident that contemporary academic research projects have only begun to investigate the economic and labour market integration of GARs.

In 2003, Simich, Beiser and Mawani conducted a qualitative study to examine the role of “...social support as a determinant of refugee well-being and migration patterns during early settlement." (Simich et al. 2003, pp. 872) The study employed a social support framework and aimed to describe the appraisal of information sources by GARs. Specifically, the authors aimed to explain reasons for GARs ${ }^{2}$ secondary migration upon landing in Canada. Simich et al. (2003) asked: 1. Under what circumstances do GARs seek support? 2. Why do GARs choose the sources of support they do? and 3. Why do they perceive this support to be significant? The authors 
interviewed 47 GARs and 38 key informants which included settlement service providers, Canadian immigration officials, and overseas visa officers (Simich et al. 2003).

Simich et al. (2003) found three salient themes. Simich et al. (2003) suggested that GARs refer to 'information as social support' when describing formal and informal sources of information about housing, employment, education and Canada as a destination. The authors explained that "[under] stressful circumstances, refugees search for what they perceive to be reliable information about their futures." (Simich et al. 2003, pp. 879) Secondly, "[upon] arrival in Canada, refugees appraise potential source of instrumental support by weighing the formal points of contact with government services - the airport, reception houses, and immigration offices - against sources of informal support such as personal contacts and perceived support in the community at large." (Simich et al. 2003, pp. 881) Finally, the authors suggested that affirmation and shared experience from integrated community members is a critical element for the settlement of GARs. "Affirmation support provides not only emotional coping assistance but also a cultural bridge in adaptation through shared experience. The need for this type of support proved to be the overriding concern for [GARs] interviewed in this study." (Simich et al. 2003, pp. 886) Simich et al. (2003) found that secondary migration of GARs is characterized as a support seeking behavior (Simich et. al 2003; see also Simich et al. 2002; Simich, 2003). Similar to other studies, Simich et al.'s research highlighted the fundamental role of social supports in the integration and settlement process of GARs (Simich et al, 2003; see also Simich, 2003; Simich et al 2002; Michalski \& Habib, 1997; Sherrell et al. 2005).

Although scholars have yet to thoroughly compare the labour market outcomes of GARs with those of refugee claimants, contemporary research has compared settlement outcomes such as access to housing, language acquisition, and use of social assistance between the two groups. 
A recent study completed by Murdie (2008) examined the housing outcomes of GARs and refugee claimants from temporary accommodation to permanent accommodation in Toronto. Specifically, the research aimed to account for the role of formal settlement assistance for GARs, through the RAP, in the provision of safe, comfortable, and permanent housing options (Murdie, 2008). The author compared GARs to refugee claimants or asylum seekers who lack a formally sanctioned support system such as the RAP (Murdie, 2008). Murdie (2008) employed the use of in-depth interviews and focus groups with 24 refugee claimants, 20 GARs, service providers, and members of the Immigrant and Refugee Housing Task Group (Murdie, 2008). Similar to the research findings of other scholars, Murdie (2008) found that GARs are at an advantage and experience a comfortable transition into permanent housing due "...to the more extensive [formal and informal] social support network" (Murdie, 2008, pp. 14; see also Renaud et al. 2003; Rose \& Ray, 2001). Murdie (2008) found that refugee claimants were regularly sharing residences and occupying smaller units than sponsored, GARs.

Meanwhile, Debeljacki's (2007) work with key informants and quantitative data from Language Instruction for Newcomers to Canada (LINC) found that compared to other immigrant groups, GARs had lower graduation rates and are least likely to enroll in LINC classes after undergoing language assessment (Debeljacki, 2007). The research findings suggested that GARs had difficulties in acquiring language skills due to challenging domestic conditions, high levels of traumatic experience, health related difficulties, lack of employment opportunities and financial scarcities (Debeljacki, 2007; see also Michalski \& Habib, 1997; Hyndman \& McLean, 2006; Brunner, 2010).

In 2006, Craig Watson carried out a quantitative analysis of federal immigration data along with provincial data on social assistance or welfare. The author aimed to identify and 
describe the predictors of social assistance, also known as income assistance or welfare, for GARs destined to British Colombia from 1998 to 2004 (Watson, 2006). The study found that "...it does not appear that source area can be consistently correlated with receipt of income" (Watson, 2006, pp. v). While the Canadian public may suppose that most GARs receive provincial income assistance, this study indicates that out of the 3,608 GARs destined to BC, only 902 , or $25 \%$ received income assistance (Watson, 2006). Watson's (2006) study affirms the relativity of research findings on the settlement and integration outcomes of GARs. First, it is clear that GARs' country of origin does not predict the likelihood of accessing social income assistance. Second, the author also concluded that GARs integration outcomes may also vary geographically, depending on where they settle in Canada.

As previously mentioned, the existing literature on the economic integration of GARs is limited in scope. Scholarly work which does comment on the economic integration of GARs treat transition into the workforce as a secondary objective of the studies. Research conducted by Michalski and Habib (1997), Danso (2002), Sherrell et al. (2005), Hyndman and McLean (2006) are examples of work on various elements of GARs' settlement in Canada. In the aforementioned studies, researchers focused on GAR groups from Iraq, Ethiopia and Somalia, Kosovo, Malaysia, and Indonesia respectively (Michalski \& Habib, 19997; see also Danso, 2002; Sherrel et al. 2005; Hyndman \& McLean, 2006; Brunner, 2010). All five studies suggest that social exclusion, housing instability, language acquisition, and lack of familiarity with the Canadian culture were the most significant barriers to the general integration of GARs (Michalski \& Habib, 1997; see also Danso, 2002; Sherrel et al. 2005; Hyndman \& McLean, 2006). Authors also indicated that high rates of unemployment or underemployment, inability to access the paid labour market, and weak employment prospects were indicators of poor 
integration and settlement outcomes of GARs (Michalski \& Habib, 1997; see also Danso, 2002; Sherrel et al. 2005; Hyndman \& McLean, 2006; Brunner, 2010). While the aforementioned research does shed light on GARs' settlement barriers, researchers are not comparing the experiences of GARs to those of refugee claimants.

This literature review found only one study which conducted a comparative analysis between the settlement of GARs and refugee claimants. Renaud, Piche and Godin (2003) conducted a study on the systemic circumstances which enable or disable job seeking abilities of GARs and refugee claimants. The authors suggested that although GARs and refugee claimants undergo traumatic experiences before arrival,

“...sponsored refugees have greater access to formal sources of information and
place greater reliance on these sources while refugee claimants [are forced to]
rely more on informal sources...refugee claimants declare their status to
immigration officials and are dependent on an immigration officer, or perhaps a
friendly taxi driver ... for initial information about shelters or other
accommodation" (Renaud et al. 2003,pp. 5).

Renaud et al. (2003) indicated that from the initial landing to finding permanent housing accommodation, GARs have the "...distinct advantage in that counselors are available to advocate on their behalf... [GARs] are helped with household furnishings and deposits for utilities. Most importantly, sponsorship gives these newcomers credibility..." (Renaud et al. 2003, pp. 5) The authors suggest that the RAP provides GARs, who are assessed on humanitarian grounds rather than human capital models, with immediate tools which contribute lasting settlement effects (Renaud et al. 2003). This study found that "[GARs] had much faster access to their first job than refugee claimants and were more likely to be employed than claimants...By two and a half years after arrival, 54 percent of the sponsored refugees had employment compared to 27 percent of the refugee claimants" (Renaud et al. 2003, pp. 4). 


\section{Evaluations of the Resettlement Assistance Program}

A considerable amount of literature evaluates the effectiveness of the Resettlement Assistance Program. For the purpose of this paper, this section will provide a brief overview of reports commissioned by Citizenship and Immigration Canada, hereafter $\mathrm{CIC}$, and scholarly research which examines the role of RAP in the settlement of GARs.

In 2002, CIC sponsored the Social Research and Demonstration Corporation, hereafter SRDC, to facilitate two day policy seminars in Toronto and Calgary (SRDC, 2002). "The primary purpose of the workshops was to discuss possible interventions to help improve the integration of government-assisted refugees (GARs) into the labour market" (SRDC, 2002, pp. 1) $\mathrm{CIC}$ aimed to investigate and find "...effective ways to increase language acquisition in order to improve labour market outcomes of [GARs] in the few years immediately following their arrival to Canada." (SRDC, 2002, pp. 1) SRDC (2002) proposed various 'interventions' in the form of pilot projects to forty eight (48) participants from eight (8) provinces (SRDC, 2002). Such pilot projects would be able to compliment the services provided through the RAP. The seminars created a discourse oriented environment where professionals could weigh the merits of each proposed pilot project based on their frontline experience (SRDC, 2002). The pilot projects suggested the creation of alternative language instruction and employment programs (SRDC, 2002). While the policy seminars did not yield a clear consensus for one particular model, "[most] participants supported the idea of testing interventions to help improve the labour market integration of government-assisted refugees ..." (SRDC, 2002, pp. 11)

In the same year, CIC funded the Power Analysis Inc. to investigate the effectiveness of RAP in Ontario. Power Analysis Inc. (2002) reviewed documents and contracts, conducted interviews with key informants of CIC, surveyed clients, conducted facility visits, and reviewed 
administrative data (Power Analysis Inc., 2002). The client survey indicated that "...RAP clients were pleased with the program overall, bestowing a B+ grade. Ninety percent said it was excellent or good." (Power Analysis Inc, 2002, pp. vi) It is important to note that as of 2003, CIC brought strategic changes to RAP by increasing the number of clients received, administering LINC instead of ESL for GARs, and opening a RAP office in Hamilton (CIC Report to Parliament, 2007).

Along with CIC sanctioned evaluations, RAP has also been explored in an academic research paper by Pradeep Navaratna (2006). The author aimed to provide a critique of the RAP by studying the settlement experiences of GARs in Hamilton, Ontario (Navaratna, 2006). Through the use of a purposive sample of participants, the author explored various dimenstions of the GAR experience which included; the a) pre-migration experience, b) arrival in Canada, c) settlement services and the resettlement process, and d) socio-economic status (Navaratna, 2006). Navaratna (2006) found that RAP was of vital importance for clients. However, the author suggested that the program, with assistance from CIC, must steer away from short term service delivery to a long term settlement support program (Navaratna, 2006). The author states “...overall, it can be concluded that the objectives of providing protection to refugees is met under Canada's Refugee and Humanitarian Resettlement Program" (Navaratna, 2006, pp. 44).

Most, if not all, evaluations of the RAP suggest that the program provides immediate settlement services in a timely manner. The critiques of the program generally advocate for the continuation of the program for GARs following the one year period.

\section{Economic Integration of Former Refugee Claimants}

Contemporary scholarship on the labour market integration of non-GAR refugees employs the use of the same theoretical frameworks which are used to study the economic 
integration of skilled immigrants. As previously mentioned, the three overarching theories which will be explored are social structural frameworks, human capital theories, and social capital theorics. While social structural frameworks investigate barriers posed by discrimination on the basis of gender, race or nativity; human capital frameworks aim to examine increased returns to educational and professional training (Trache \& Sweet, 2005; see also Ferrer \& Riddel, 2008). Meanwhile, social capital theories suggest that transition into the labour market requires immigrants to tap into their social ties to secure jobs. Here, social capital theories emphasize that what you know rather than who you know is valued in the labour market (Matthews, Pendakur \& Young, 2009; see also Delattre \& Sabatier, 2004; see also, Wahba \& Zenou, 2005).

In the Canadian context, human capital frameworks have been used by DeVoretz, Pivncko and Beiser in 2004 to examine the economic integration and labour market outcomes of refugees from $1980-2001$. Specifically, DeVoretz et al. (2004) aimed to investigate ways in which Canadian policies affected refugees' economic performance after arrival (DeVoretz et al., 2004) The authors examined a) length of time required for refugee economic integration, b) refugees' use of Canada's social safety net, c) refugee poverty levels and d) the economic performance of refugees compared to the family immigrant class (DeVoretz et al., 2004). The main research findings indicated that the employed refugees' earnings equaled the earnings of the family class reference group "... both at the time of their arrival and in each successive year of residence" (DeVoretz et al., 2004, pp. 29: see also DeSilva, 1997). The authors found that most newcomer groups, including refugees, needed the same amount of time to integrate into the Canadian economy (DeVoretz et al., 2004). Similar findings were evident in DeSilva's (1997) study of male immigrants who had landed between 1981 and 1984 (DeSilva, 1997). This study also indicated that "... although independently selected immigrants were the highest foreign born 
income earners, they experienced the smallest earnings growth after arrival. In contrast, the designated refugee class reported the most rapid increase in carnings." (DeVoretz et al., 2004, pp. 8: referencing DeSilva, 1997) Such research findings are remarkable, given that refugees had the weakest command of both of the official languages upon landing (DeSilva, 1997).

Social structural frameworks were used by Krahn, Derwing, Mulder and Wilkinson in 2000. Krahn et al.'s (2000) study used the Settlement Experiences of Refugees (1998) survey to investigate the accessibility of 'high-status' occupations for high-skilled refugecs. The study incorporated interviews with 525 adults who were resettled in Alberta between 1992 and 1997 (Krahn et al., 2000). In terms of the educational and occupational qualifications prior to arrival, the study indicated that $25 \%$ of the refugees in the sample were highly educated and came to Canada with a university degree (Krahn et al., 2000). Of the 525 adults in the sample, $16 \%$ had a strong affiliation with a certain trade or had participated with vocational programs prior to arrival (Krahn et al., 2000). Furthermore, $43 \%$ of the entire sample participated in some sort of post secondary program such as colleges, universities, vocational schools or private training (Krahn et al., 2000). "The comparable figure for the Alberta population of 20 -to 64 -ycar-olds is $49 \%$ [with postsecondary education], according to the 1996 Census, with only $18 \%$ reporting a university degree" (Krahn et al., 2000, pp. 63). By comparing the refugec population with the mainstream population of Alberta, the study found that $25 \%$ of refugees had a university degrec compared to $18 \%$ of the mainstream population (Krahn et al., 2000). Furthermore, while the population of Alberta had a slightly larger percentage of total persons who attended some sort of post secondary program, the differences between the two groups was only $6 \%(43 \%$ - refugee group, $49 \%$ Alberta population). The study demonstrated that while refugees are granted asylum based on humanitarian need rather than human capital, they are often highly educated and have made 
tremendous contributions in their countries of origin. While there may be an assumption that immigrants from European countries of origin have higher human capital, in terms of educational attainment and professional background, this study indicated that refugees from Africa, Central America, and Southeast Asia had a larger percentage of professionals than European countries such as Yugoslavia (Krahn et al., 2000). Nevertheless, the author concluded by stating that barriers to the economic integration of skilled refugees were associated with visible minority status, lack of Canadian work experience, credential recognition difficulties and a variety of other structural factors (Krahn et al., 2000: see also Hiebert, 2009: Zietsma, 2010: Trache \& Sweet, 2005).

While the presence of credentials in the country of origin and visible minority status may play a role in the economic integration of refugees, some scholars suggest that it is more "who you know' rather than 'what you know'. The use of social capital frameworks is evident in Lamba's (2003) work on the economic integration of refugees and social networks. Lamba's (2003) work also draws on the Settlement Experiences of Refugees (1998) survey carried out in Alberta to investigate the role of social capital on refugees' quality of employment. Lamba's work examined a) the role of refugees' former occupations and education, b) level of fluency in the English language, and c) training received in Canada in relation to the worth of social networks in gaining meaningful employment (Lamba, 2003). The author asked participants about a variety of social networks including a) their proximity to close family members, b) the presence of extra-familial ties, and c) the network ties which were responsible for helping refugees find a job (Lamba, 2003: see also Zietsma, 2010). The results indicated that most refugees' quickly forged social ties and networks to accommodate or compensate for the inefficient use of their human capital (Lamba, 2003). The study found that $1 / 4$ of all participants 
interviewed, used social ties and networks to find employment (Lamba, 2003). Lamba's (2003) study found that although "...network ties, particularly in-group ties, may be helpful in locating employment for refugees...they cannot restore refugees' previous occupational status" (Lamba, 2003, pp. 58; see also Dorantes \& Mundra, 2004).

Trache and Sweet (2005) correctly suggest that "[while] social structures obviously constrain immigrant integration, employers nevertheless do take into account the human capital and personal [individual] characteristics of their current and potential employees" (Trache \& Sweet, 2005, pp. 182). Previous work experiences, educational background, field of study, linguistic aptitude, or networking ability are all variables which enable newcomers, including refugees, to integrate into the Canadian workforce.

While a comprehensive analysis and review of the literature has provided a thorough background of current research findings, it is clear that research in this area is scarce. Given the steady flow of refugees from diverse countries of origin, “...it is appropriate to ask how these various refugee groups fare over time in the Canadian economy" (DeVoretz et al., 2004, pp. 4). Previous research on GARs has primarily focused broadly on their immediate settlement experiences. Relatively little scholarly debate has been devoted specifically to the labour market experiences of refugees. While some scholars have briefly addressed the economic integration of inland refugees, minimal attention has been paid to the economic integration of GARs.

The economic integration of GARs has not been explored and their economic outcomes have never been compared to those of refugee claimants in Canada. While refugee claimants face logistic barriers, with respect to claim processing, social barriers such as isolation, and status constraints; GARs become permanent residents upon landing and are provided with a formal resettlement program. This program plays a crucial role in the immediate settlement and long 
term integration of GARs. This literature review suggests that there is a gap in the available research. Although researchers have minimally studied the settlement and integration outcomes of refugees and GARs separately, it is imperative to further investigate, compare, and contrast the labour market integration of GARs to those of refugee claimants. Conducting such a comparative study between GARs and refugee claimants will also identify the role of RAP as an effective mechanism, or lack thereof, in the immediate settlement and long term integration of refugees. Such an endeavor will also be able to demonstrate which theoretical framework or collection of frameworks best explain the labour market integration of GARs and refugee claimants into the Canadian workforce. 


\section{Methodologies}

The purpose of this research project is to investigate, compare, and contrast the labour market integration of former GARs and former refugee claimants. This rescarch study aims to identify the tools used by two refugee groups to transition into the Canadian workforce. To do so, this study employed the use of qualitative research methods by conducting semi-structured interviews with former GARs and former refugee claimants. In this study, former GARs refer to individuals who were sponsored by the federal government upon immigrating to Canada. Former GARs gained permanent resident status and ultimately became Canadian citizens. Similarly, former refugee claimants are individuals who were once secking convention refugec status in Canada. Former refugee claimants gained convention refugec status, applied for permanent residency, and ultimately became, or are on the way of becoming, Canadian citizens.

To recruit volunteer participants for this study, six service provider organizations in Hamilton and in Toronto were used as avenues for recruitment. Administrative bodies within these organizations were briefed about the research project and assisted in the circulation of recruitment flyers and emails amongst their employees. The research project sought to recruit a purposive sample of participants who:

1. Were former Government Assisted Refugees or former Refugee Claimants

2. Have resided in Canada between 5 to 15 years

3. Are currently working in service provider organizations or within the social service sector

Approximately 600 employees working at service provider organizations in Hamilton and Toronto were contacted through email and provided with information pertaining to this research project. Information provided to organizations highlighted that participation in this study is voluntary. Both the email and recruitment flyer specified that employecs should not feel 
compelled to partake in the study simply because the origin of recruitment is from the workplace. Furthermore, the project overview cmphasized that refraining from participation will not affect the employees' relationship with their employers.

Service provider organizations included the St. Joseph Immigrant Women's Centre, the Good Shepherd Centres, YMCA Immigrant Settlement Services, COSTI Immigrant Services, and the Centre for Women of Colour. The aforementioned service provider organizations provide programs, services and settlement supports to members of diverse communities including newcomers. The programs and services include, but are not limited to, shelters, housing supports and advocacy, mental health programs, therapeutic services, language assessment programs, language instruction programs, interpretation services, violence and crisis support, food banks, recreational programs and referrals to other agencies.

Working in social service occupations enables the employees of these organizations to work with Canadian born populations as well as newcomers. Conducting interviews with individuals who have qualities such as a) firsthand experience in integrating into the Canadian labour force, as a former GAR or former refugee claimant, as well as b) having professional expertise in facilitating the settlement of other refugee groups makes them ideal candidates. These individuals will simultaneously be able to act as key informants and interview participants.

Given the stringent time constraints, over the duration of one (1) month, four (4) individuals contacted the principal investigator to partake in the research project. By recruiting former GARs and former refugee claimants who are currently employed in similar spheres of work this study was able to control for approximate linguistic aptitudes. Furthermore, this recruitment method would ensure that participants' educational background in their country of origin or the education they acquired in Canada are from similar fields of study. Given that the 
participants have lived in Canada between 5 to 15 years, ensured that the participants were permanent residents or citizens and could confidently reflect on their experiences.

Prior to partaking in the study, the participants were briefed about a) the extent of their participation, $b$ ) any harms/risks associated with their participation, c) their ability to opt out of the study at any given time, $d$ ) their right to abstain from answering any questions, and e) matters of confidentiality. Consent forms outlining the aforementioned ethical areas were signed by participants of this research project.

The participants and principal investigator took part in one to two hour informal interviews using guiding questionnaires. While the same guiding questionnaires were used for all four participants, the content of the discussions varied. Participants discussed themes, concerns, and memories relating to their experiences transitioning into the Canadian labour force.

The interviews were audio recorded, with the permission of the participants, and were professionally transcribed. Following transcription of the audio files, the semi-structured indepth interviews were analyzed and common themes were identified.

While in-depth interviews do yield rich qualitative data, such research methods also have limitations. First and foremost, the power imbalance which occurs between the researcher and the 'study participant' or 'research subject' must be addressed. During interviews, it is often the participants which reveal "...personal and intimate detail of their lives, only then to have these accounts objectified, dissected and scrutinized" (Reynolds, 2002, pp. 300). The researchers offer little personal accounts and tend to control the research process (Reynolds, 2002). Furthermore, the researchers are in control of how the data is to be analyzed and what conclusions can be drawn from the experiences of the participants. To ensure that participants felt comfortable, the interviews were strategically conducted in quiet locations such as public library rooms. 
Furthermore, it was made clear to the participant that they may inquire about the researcher's experiences relevant to the discussions as well.

Time constraints also posed as a shortcoming of the recruitment methods. As a result, this research project had approximately one month to begin and complete recruitment of participants. If more time was allocated for the recruitment of participants, perhaps a more representative sample of informants could have been interviewed. Furthermore, an equal number of former GARs and former refugee claimants could have been recruited. This would have provided for a more thorough analysis of the similarities and differences between the two groups, when transitioning into the Canadian workforce. 


\section{Research Findings}

\section{Participant Profiles}

In part due to stringent time constraints and a recruitment period of one month, four informants contacted the primary investigator to participate in the research project. Although four interviews certainly cannot provide a representative sample of all former GARs and former refugee claimants, the interviews provided for a careful glimpse into the lived realities of the refugee experience. The participants' shared their lived, and often painful, experiences which serve as the most objective depiction of the refugee experience. This research project utilized qualitative research methods and as such aimed to analyze in-depth interviews with participants who were former refugees and simultaneously key informants. The participants recruited for this project did not only discuss their own personal memories and recollections but also their professional expertise. Having worked with other refugees in different capacities, their feedback and insight provided for interesting and rich interviews. While overall it was very difficult to recruit willing participants, it was less difficult to locate and recruit former GARs than former refugee claimants. Although many variables may have impacted this outcome, it is important to consider that former GARs may have better tools to integrate into various social service professions than former refugee claimants. Finally, for reporting purposes I am emphasizing a desire to preserve the confidentially of participants. I will therefore be referring to interviews based on former refugee status and continent of origin.

The profiles of the participants were as follows:

- The informants came from different countries of origin. The countries of origin included Middle East, Southern Africa, Western Africa, and Eastern Europe

- The age of informants ranged between 24 to 51 
- The participants consisted of three women and one man

- Three of the participants were former Government Assisted Refugees and one participant was a former refugee claimant

- All four of the participants worked in social service provider organizations in Hamilton

- The participants work as settlement counselors, managers and executive directors of immigrant serving organizations, and personal support workers

- The research participants lived in Canada between five to fifteen years

- For three of participants in this study, Canada was a secondary migration destination. Meaning that they moved from their homeland elsewhere, prior to coming to Canada.

- Three of the participants chose to stay in Hamilton, upon immigrating to Canada

- Three of the participants had a university education and worked in professional occupations prior to displacement

- All four participants attended post-secondary educational institutions following their arrival to Canada

\section{Refugee Experiences}

The main objectives of this study are to investigate and understand the paths used by former GARs and former refugee claimants to transition into the Canadian workforce. The semistructured interviews provided a rich source of data. Although the main purpose was to focus on the economic integration of the participants, all four informants included brief accounts of their refugee experiences prior to immigrating to Canada. Such accounts are important to consider since they shape the informants' refugee experiences and memories of displacement. While experiences discussed by the four participants varied it was clear that most of the informants, three out of four to be exact, moved to a secondary, host country, prior to immigrating to 
Canada. In all four interviews, informants experienced forced displacement from their countries of origin due to civil war, political persecution, and religious persecution.

I'm Baha' $i$ and we're discriminated against in [my country of origin] and all that...I actually had an uncle who was murdered too... we 've had a few incidences where my dad was taken away and brought back..., all we had was our backpacks on our backs. That is all we had going into another country. [Middle East, Former GAR]

I came as a refugee of the war, when the war broke out in [my country of origin]. [Eastern Europe, Former GAR]

After fleeing to the host countries, the informants' continued to experience poor living conditions, ill treatment, and even war which contributed to a difficult refugee experience.

I was born in [Southern Africa] and I was a journalist in [Southern Africa] ... and then because of my profession, there was a time there where my government started prosecuting and persecuting journalists and so I left, I fled. I fled through two African countries to get to the United States. [Southern Africa, Former Refugee Claimant]

[We] sold our stuff and paid a smuggler... I know it sounds horrible ... and then we came to Turkey through the mountains and the mines. If you are in Turkey you can get deported if your case is not accepted by the UN. We were thankful that we got accepted after like a year...we first arrived to Toronto. [Middle East, Former GAR]

We came from [Western Africa]. During our Civil War in 1990, we fled to [another Western African country] and war started [there] in 2002. We fled to Kenya ... Republic of Kenya. So we moved to two countries before coming to Canada. [Western Africa, Former GAR] 
During the intervicws the informants recalled specific incidents which embodied their refugee experience. One participant recalled the experience of being detained in the host country, prior to being rescttled in Canada.

We got caught by the Turkish soldiers. I remember this exactly. They started shooting and our smuggler ran away. It was just my family and we dropped to the ground. They started shooting at us and I had goosbumps. I thought my dad was dead. I started crying. I still remember the shooting... it was so loud. [Middle East, Former GAR]

We were just thankful that there were other people in the same boat as us. We would gather and we would pray... I remember the jail and the prayers. They shaved my dad's head. He was in a small cell by himself. Me, my brother, and my mom were in another bigger cell and we were still treated like shit. [Middle East, Former GAR]

Although the participant has been residing in Canada for 14 years, listening to Turkish music reminds her of her family's struggles in the host country. The informant shared that while being caught and detained in the Turkish border was dangerous, the family attempted to escape again in search for a better and bearable life. Similarly, all four informants recalled incidents during which their family's physical well being may have been jeopardized. Nevertheless, the informants had no choice but to take on the risk in search for a safe life free from persecution.

The three informants who were former GARs reported that the role of the UNHCR prior to their resettlement in Canada was necessary for their livelihood. Informants recalled having to move to the nearest UNHCR office for assistance. Participants also shared that they received information, protection, and minimal assistance with basic needs prior to being resettled. Former GARs did not have many personal resources while under the protection of the UNHCR in the refugee camps. 
Right there in Africa ...they had people that tell us what not to do...that the government will support you and they will stop. So that people can get prepared. They told us the government will help us. [Western Africa, Former GAR]

If the UNHCR did not have refugee camps at the host country, displaced refugees would often be provided with other forms of accommodation while waiting for the processing of paperwork or to be resettled.

Everyday my dad would have to go to the UN and sign papers and there were so many things that I wasn't aware of. If you are in Turkey you can get deported if your case is not accepted by the UN. You get deported back to [my country of origin] and that's it, your life is shit. We were thankful that we got accepted after like a year. Usually for some people it would take two or three years. But we were so lucky. [Middle East, Former GAR]

Meanwhile, the former refugee claimant reported that the decision to move to neighboring countries and claiming refugee status in the United States and later Canada was a personal decision. The informant was well established in the country of origin and had the financial resources to be able to sustain her family in Canada while her claim was being processed. Both former GARs and the former refugee claimant underwent a period of uncertainty which further made their refugee experiences difficult.

\section{Immediate Settlement Experiences}

While all four participants shared similar refugee experiences prior to being resettled or immigrating to Canada, the informants' settlement experiences differed along status lines. More specifically, the interviews indicated that the settlement experiences of former Government Assisted Refugees and former refugee claimants depended on their eligibility, or lack thereof, for services and supports in Canada. From conducting interviews with informants who were former GARs and former refugee claimants, it is clear that the support, guidance, and advocacy which are provided to GARs are not provided to refugee claimants. When in-land asylum seckers claim 
refugee status, they often undergo a lengthy claims processing period in Canada while waiting to become convention refugees. The research participants reported that the period during which their refugee claim is processed is filled with uncertainty and causes a great deal of frustration and stress.

When I first came to Hamilton they told me straight out, they told me the government that there is no organization that is going to help you. You are on your own...refugee claimants...that itself was a very frustrating status to be and to have. I went through no credit, I went through racism, I went through living in slums and when I asked to get preferential treatment because my son is [ill], I didn't get it... Here is my reality I hated being a refugee claimant. I could not go to school. I could only go to remedial school because I was a refugee claimant... wherever I went, my status stood in the way. Everywhere I went, my choices were closed and they were limited. [Southern Africa, Former Refugee Claimant]

The stress and frustration is caused by uncertainty and ineligibility of services due to refugee claimants' status. The participant reported that from the onset their status stood in the way of their active settlement and integration in Canada. The participant felt as though their life was on hold until their status was determined. Omidvar and Richmond (2003) refer to this period of uncertainty as a 'legal limbo' during which refugee claimants "...face significant barriers in access to social services...[refugee claimants] can't get a bank loan, or vote, or work in certain professions, they can't travel internationally...and they can't get loans for post-secondary education" (Omidvar \& Richmond, 2003; pp. 5; see also Wayland, 2006). The authors add that “... it is common for this situation to last five years, or more." (Omidvar \& Richmond, 2003; pp. 5; see also Wayland, 2006) The 'legal limbo' serves as a negative immediate settlement experience for refugee claimants "...during the first few years of their life in Canada - the years most important to successful settlement." (Omidvar \& Richmond, 2003; pp. 5; see also Wayland, 2006; Mohamed, 2002) 
Contrary to the experiences of former refugee claimants, former GARs did not recollect the same frustration and stress. Instead, former GARs reported that they experienced a period of adjustment to the weather; taste of food and to certain social norms upon their arrival to Canada.

Because when we got here, we slept one night in a hotel. The next morning it was snow. It was our first time seeing snow, my son went outside, ran from the hotel to his sister's house thinking he didn't know that snow is cold. He put on his jogging shoes and got sick for a week. [Middle East, Former GAR]

We first lived in Toronto for like a week. All I remember is like we were given a room with bunk beds. I guess they were trying to do the paperwork with my parents. I remember me and my brother would go to programs and we spoke no English. We didn't know the language and my parents too. We were given support. I mean when you first come here you are homesick. It's a huge chance. Especially if you don't know the language and you don't have supports. [Middle East, Former GAR]

When we are going, we didn't know you have to walk side by side, we make a long line behind one another. Right there in Africa. They had people that tell us what not to do. [Western Africa, Former GAR]

Similar to Navaratna's (2006) findings, former GAR informant's first impressions of Canada were positive. Given that GARs become permanent residents upon arriving to Canada and are provided with the assistance of the RAP, feelings of uncertainty and frustration are minimized. Former GARs reported that the first point of contact with interpreters at the airport signaled a welcoming feeling. The major changes experienced by former GARs can best be characterized by a feeling of adjustment.

Both former refugee claimants and former GARs informants reported that the presence of social supports such as members of the same ethno-cultural community, religious community or extended family were very important to their immediate settlement experiences. While the presence of such supports alleviated stress and served as sources of information, the absence of 
extended family members caused the informants additional discontent. Similar to the findings of Simich et al (2003) one informant reported that presence of extended relatives in another city persuaded the family to move from Toronto to Hamilton.

Q: Why did you decide to move to Hamilton?

R: Yes because we had an uncle here. He had moved here a while ago, about 15 years before 1997. He escaped right away when the whole Revolution happened... We lived with him for a month or two. We were given support. I mean when you first come here you are homesick. It's a huge change. Especially if you don't know the language and you don't have supports.

Q: What is the role of the presence of a community...say for example [the] Baha'i community's presence upon coming to Canada?

R: Huge. Of course... When you come here, they can tell you their ways of coping and adjusting and you can adopt their ways. They give you the feeling that everything is going to be okay. You become friends and they are there for you when you need it. [Middle East, Former GAR]

The former GAR informants shared that while the presence of extended family members was useful; the RAP facilitated the family's introduction to their ethno-cultural and religious community members. Such connections further reassured the informant's family and assisted with their immediate settlement needs. Meanwhile, the absence of social supports caused greater aggravation for former refugee claimants who had limited resources from the onset. The informant reported that the absence of social supports lead the informant to forge alternative social ties. The informant also suggested that due to the ineligibility to services refugee claimants must learn to 'maneuver the Canadian system' on their own.

Q: Did you have any family or friends in Canada, prior to coming here? 
R: No. Just my son and I... yes my son and I. I didn't have friends or family. I still don't... My lawyer, believe it or not was my best friend and he was my consort and my confidant that ... to him I went and it was to him ... you know he would tell me what to do and how to do it. He didn't have to. But he did. He for like the two years ... he supported me and he would tell me well maybe not this try that try this...he said...it's going to be very tough for you. So I logically used my own ... because I travelled to South America so I used my expertise to maneuver and it was not easy. Not easy at all. [Southern Africa, Former Refugee Claimant]

It is also important to note that even after convention refugee status has been granted, former refugee claimants continue to struggle with accessing services due to immediate settlement experiences of isolation.

When I first came to Hamilton they told me straight out, they told me the government that there is no organization that is going to help you. You are on your own...You have to sort yourself out and go with it...So I did not really use the system, because every time I tried to use the system...they were biased.

Q: Because you were a refugee claimant?

R: Yes... but there were other services they could have given me. They didn't refer me, they didn't do anything. I was bored out of my mind. [Southern Africa, Former Refugee Claimant]

The interviews revealed that all three former GAR benefited from the initial resettlement services provided by RAP. Informants recalled that the services and supports were at times basic but well needed. One informant suggested that the RAP's services and supports served as a 'cushion' for GARs which assisted with their settlement process. Furthermore, RAP's services allowed former GARs to adjust to life in Canada.

...the only type of connection that we had in the city of Hamilton was a distant relative ...but really in terms of services we did not depend at all on that we depended largely on settlement services in Hamilton. [For] Government Assisted Refugees...basically at that point it was support with some paper work with information about very basic settlement services. [Eastern Europe, Former GAR] 
We were given rent for 1 year, food for a year...basic furniture, and [LINC]. In terms of ... the rent for one year helped a lot, the food, the furniture... especially if you don't have the money... we did live with my uncle for a few months...Then we found a place. We came here with nothing... what they provided us with was great. I mean one year rent was good...the food is amazing, and the fumiture is well needed. We got the very basic help that you get when you get here. [Middle East, Former GAR]

Q: How did the resettlement program help you... in what way?

R: To know what to and not to expect. They taught us to keep every receipts... what the RAP program did for us was again that had been tremendous help for us. We went through it. Right now we are glad that we are here. Even that first year, it was difficult but we are glad that we are here. We started helping people back home, the little money the government was giving we started sending back home to help. [Western Africa, Former GAR]

Informants reported that having permanent residency and a formal organization assist in their settlement process gave them confidence. Former GAR informants began to adjust to life in Canada shortly after arrival, while former refugee claimants experienced 'legal limbo'. More importantly, it is apparent that the immediate settlement experiences of both former refugee groups affected their long term perceptions of life in Canada. All four informants identified the existence of social supports as an additional form of assistance in their settlement experience.

\section{Transition into the Workforce}

Upon discussing transition into the Canadian workforce, both former refugee claimants and former GARs shared experiences with similar themes. All four informants reported that several elements contributed to their entrance into desired social service related fields in Canada. Participants suggested that the key pathways used to transition into the workforce were a) their educational background in the country of origin, b) their professional background in the country of origin, c) further post secondary studies in Canada, d) volunteering experience after arrival, 
and e) networking with professionals in the desired fields. While this section will provide a thorough overview of these elements, an in depth analysis of these findings will take place in the discussions section.

The interviews revealed that three of four participants held university degrees and had professional experience within their fields prior to immigrating to Canada. The one informant who did not have a university degree or professional experience from their country of origin came to Canada as a student and pursued further secondary and post secondary schooling. Informants confidently shared details about their former occupations and, in most cases, desired to work in the same fields. When asked about their professional background in their countries of origin the interviews revealed that they held highly prestigious positions in their capacities as lawyers, social workers, and journalists. One participant worked for the Ministry of Internal Affairs while another "...won lots of journalism awards in New York". All three participants who came with foreign qualifications identified themselves with their professions in the present rather than in the past.

Q: Prior to coming to Canada, what was your professional background in your country of origin?

R: I was a lawyer... I am still a lawyer but was a practicing lawyer at that time. Now my [spouse] is a family physician back there but [my spouse] managed to go through the process and [they are] now practicing here...same as my [siblings] ...now that was a very stressful process. [Eastern Europe, Former GAR]

Overall, informants were highly educated and skilled prior to arrival and held prestigious professional positions. All four informants reported that upon arrival to Canada, immediate settlement needs took precedence over educational and professional aspirations. Informants worked hard to learn the language, become informed about their rights and responsibilities, gain knowledge about the healthcare, education and transportation systems, find permanent housing 
and adapt to the Canadian way of life. Former GAR informants reported that they were provided with advocacy, counseling, and life skills assistance throughout this process. Income assistance supported the former GARs by ensuring that they use their first year in Canada to adapt to their surroundings, the climate, and the Canadian way of life.

Government sponsored programs of any kind are extremely helpful for [GARs] because they provide that initial financial support...GARs who come through that program, because of...trauma and all of that stress... because they come mostly from wars or living in a camp... or refugee like camps...overseas ...they go through many different issues, personal issues and emotional issues and they would not really be ready for work right away so that program gives them a little ... like a cushion time so they can recuperate like emotionally... [Eastern Europe, Former GAR]

Contrary to former GAR informants, the former refugee claimant reported that while the claim was being processed, the participant actively sought out volunteering and educational programs to secure employment. However, the participants' status continued to pose constraints and now stood in the way of transitioning into the Canadian labour force.

All four participants attended post secondary institutions, including universities and colleges, after arrival in Canada. One participant completed a college diploma and is now working on a university degree. In all four cases. informants were required to juggle financial responsibilities, managing the home, and child rearing while simultaneously attending programs at post secondary institutions. The financial and emotional toll was repeatedly emphasized by informants.

My dad got a job at Swish Chalet ...but he went to school while he worked there. He went to Mohawk to be a mechanic because that's what my uncle was. He was really interested in that... They couldn't go to school back home they didn't have the opportunity back home so when they came here they were motivated to go back to school...My mom...she went back to school also. She went to dental assisting school... She's had a hard time finding a job but she still volunteers with them. [Middle East, Former GAR] 
I do my nursing...I do evening and night shifts. During the day I go to school. At first I wanted to go into the Social Work field...It was not easy and I studied hard but I couldn't so I changed to women's studies. I worked with women and children a lot back home. So it's nothing new to me. I am doing courses to get into mursing and women's studies courses are sometimes accepted for nursing. So I am just crazy with courses. At my age, with 5 children, their going to school and I am going to school, it is just not easy. [Western Africa, Former GAR]

I am doing two degrees at the same time and I will be finished next year. It's a lot of work. But I'm thoroughly having fun and I will get into a masters degree. And then after I do my masters degrees next year, I will do my PhD... At the end of the day I want to teach at a University or College. Teaching will enable me to write and it will enable me to be an activist. [Southern Africa, Former Refugee Claimant]

I took a couple years after high school off and I didn't know what I wanted to do. I was so lost and I didn't know what to do with my life. But then I came to university because I realized that my parents worked so hard to bring me here. What am I doing, I was wasting my life...Me graduating from university was a big deal for them. I was the first person in my family to graduate from university and so it was huge for them. [Middle East, Former GAR]

Now education, it is again very important, especially in professional fields...if you want to go. Because of license requirements, unless you have certain credentials you cannot become a practicing social worker in Canada or physician, or dentist or engineer or architect. You name it. [Eastern Europe, Former GAR]

The three participants who had professional experience and university degrees from their countries of origin reported working in different professional fields in Canada. Informants reported that difficult accreditation processes and the burden of unrecognized foreign qualifications deterred them from pursuing former professions.

It was tough...you either need to completely change your profession ...or if you decide to go in your field of occupation you may [need to] count on a couple of good years for example 5, 6, or 7 years it took for my all rest of the family doctors to go through 
the process and you know start to practicing here and getting their license. [Eastern Europe, Former GAR]

Journalism is a specialized field. It is like medicine...So it's difficult to get a job as a journalist with foreign qualifications amywhere in the world... 1 think that the government of Canada lets people down in that instance because these are their rules and their regulations. No foreign qualifications of any kind, no foreign this, no foreign that you have to be strictly Canadian. You have to be at a totally Canadian school to get an English diploma otherwise you don't got English. [Southern Africa, Former Refugee Claimant]

It was a stressful time because ... when you are a professional and you are aware of certain knowledge and skills that you bring and yet because of your credentials are not recognized, you have two choices, either give up which I think is not a choice for most refugees or any newcomers to Canada, or just continue to struggle with... between finding a job, working, and studying. [|Eastern Europe, Former GAR]

It is also important to note that prior to gaining employment to in their current, social service related professions, informants undertook strenuous, labour intensive jobs, which required little specialized skills. Such jobs included working in packaging factories, telemarketing, and fast food delivery. However, both former GAR and former refugee claimant informants reported that previous education from their countries of origin provided them with a foundation which was necessary to adapt to the Canadian labour force. Transitioning into the workforce was made manageable since informants came with a certain professional and educational background. The knowledge informants had gained in their countries of origin provided them with the skills necessary to navigate various educational processes as well as seeking employment.

It was an opportunity but what helped me get that settlement worker job at that time [and] was my ability to become familiar with the services in the community and that is where my previous education played a role because I could use some of the skills and figure out how the system works and where I should focus and what I should concentrate on and how should I prepare for potential jobs. [Eastern Europe, Former GAR] 
It is difficult to get employment. The only reason I did is because I am me...I am not saying I am special but I came with a certain set of skills...that helped a lot. Coming from the US helped me a lot. It gave me a cushion and at work they would acknowledge America. It makes me think of that refugee who comes straight from Africa or who comes straight from the Middle East who does not have...

[Southern Africa, Former Refugee Claimant]

The interviews also revealed that both former refugee claimants and former GAR participants placed great emphasis on volunteering their time. Informants acknowledged that volunteering would enable them to socialize within professional settings and introduce them to potential career opportunities. Overall, informants perceived volunteering as a means of being introduced to work environments and serving as source of information.

\section{I just said okay my country taught me that volunteering is a wonderful thing and why don't I just go do that..I decided to volumteer and I was still a refugee claimant. I decided to volunteer. I went to [an organization in] Hamilton, I went and said I'm a writer ... I'm a published author... I want to volunteer. They took me, I guess at that time they must have thought I was very good at what I did... [Southern Africa, Former Refugee Claimant] \\ ...because of my transferable skills and because I started volunteering, I was employed very early... [Eastern Europe, Former GAR]}

Informants reported that being surrounded by other immigrants who are working empowered them. Participants were felt encouraged and regained the confidence needed to seek employment. Furthermore, volunteering provided informants with an opportunity to better their linguistic skills and gain Canadian experience.

Three of four participants suggested that along with volunteering and enrolling in post secondary educational programs, networking with professionals from their desired fields was very important. In fact, networking was perceived to be a vital element which led both former GARs and the former refugee claimant in securing employment in Canada. The specific type of networking which was deemed to be a significant resource was identified as forging ties with 
individuals outside of one's own ethno-cultural community. Informants placed great emphasis on forging networking tics with other professionals within social service fields. Similar to the findings of Mathews, Pendakur and Young's (2009) study on the role of networks, the informants suggested that forging social ties with individuals from targeted occupational backgrounds supported them in securing employment. Like Lamba's (2003) findings, participants reported that in group ties with individuals from their ethno-cultural communities also provided opportunities for securing work. However, such work opportunities often did not fall into professional fields which required a specialized set of skills and knowledge. Instead, participants reported that ethno-cultural or in group ties offered informants work in labour intensive jobs (Lamba, 2003). Informants were very clear about the different types of social ties and the different ways in which such networking is used to secure employment.

I did not find that the community from my own ethnic group was helpful at all I mean it was not because most of the people were not doing ... I mean professional education... but what I did find helpful was connecting with mainstream professionals and education ... these two helped me go ahead I think and exceed my careers in Canada. [Eastern Europe, Former GAR]

The Baha'i community is not just Iranians. The Baha'i faith is very multicultural so you get that exposure. You talk to [Middle Easterners] and [non-Middle Easterners] and you are learning the language...Finding jobs is that's the one thing... even though it's a religious organization or group you are able to find jobs and learn the language; because it's a diverse group and community... [Middle Easter, Former GAR]

Social networking is immense. Now social networking specifically within your own specific ethno-community group ... that kind of networking leads you to certain jobs... Lets say communities that are... pretty much into pizza business. Not to generalize because that is really not true. But lets say you think of pizza stores, and most of them in Hamilton are run by people who are Persian or Iranian...in that sense community is crucial to find those kind of labour driven jobs. But social networking is hugely important if you are in a professional field. If you are an Afghan engineer and 
you want to make it into that field and explore different opportunities with different companies then ... you will find much less support or importance of your Afghani community in that field. But it would be crucial to know mainstream Canadians regardless of how you define them...you need to be able to connect with associations, with people involved in that field who will provide you with some mentoring and support in that field... [Eastern Europe, Former GAR]

Overall, former GAR and former refugee claimant informants placed great emphasis on educational aspirations. While former GAR participants transitioned into the workforce after meeting their immediate settlement needs, the former refugee claimant was required to address settlement needs and seek work simultaneously. Former GAR informants also reported that the RAP assisted them in forging in group social ties with members of their ethno-cultural and religious associations. One former GAR from West Africa shared that RAP facilitated her transition into her current profession by referring her to a bridging college program in Hamilton. Former GAR informants also reported that referrals to other service providers and programs in the city provided them with further networking opportunities. One informant shared that a RAP referral introduced her to an arts organization which began assisting her by funding her artistic endeavors. This informant was able to sell her art work to supplement her income from her current position.

That's why we came here; our safety and education; because they could not go to school and they wanted us to go to school. That was our safety, a better lifestyle and education. [Middle East, Former GAR]

what helped me get that settlement worker job at that time was the ability to become familiar with the services in the community ...because of my transferable skills and ability to gain some of the language skills and because I started volunteering, I was employed very early... exactly in 2 years time ...I was employed by a settlement agency in Hamilton as a settlement counselor. That is how I got into the labour force. [Eastern Europe, Former GAR] 
The average number of years spent in Canada, for all four research participants, was eight and a half years. The three participants who arrived with educational and professional experience from their country of origin began working within two years after arrival. Figure 1.1 provides a visual depiction of the reported pathways to professional fields as identified by former GAR and former refugee claimant participants. The visual representation of the research findings clearly displays the similarities between informants who are currently employed in service provider fields of work.

Figure 1.1

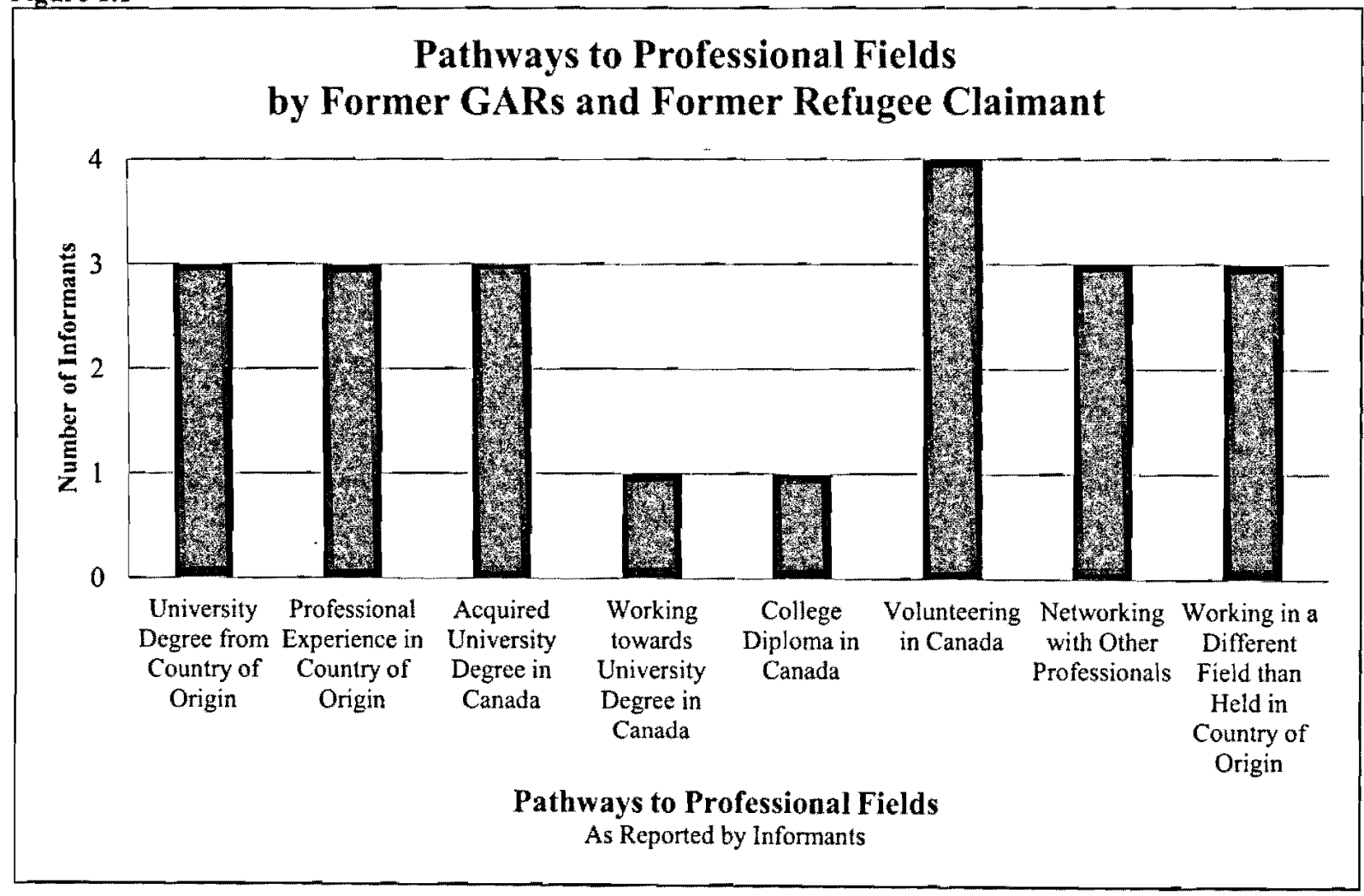

\section{Working with Other Newcomers \& Suggested Changes}

Not only did all four of the participants have personal insight into the refugee experience, the informants have also been working with other newcomers and refugees in various capacities. 
The informants' current professions, within Hamilton's social service sector, have enabled them to gain specialized knowledge and skills pertaining to the settlement process of immigrants. As settlement workers, executive directors of non-for-profit support agencies, managers of settlement programs and personal support workers, the participants contributed insight into ways in which a) programs and services meet the needs newcomers, b) ineligibility of refugee claimants to programs and services, c) systemic barriers for newcomers, and d) proposed changes to the current system of service provision.

Both former GAR and former refugee claimant informants thought that the RAP provided GARs with key programs and services, necessary for immediate settlement in Canada. Informants reported that the advocacy and support provided by the RAP aimed to empower GARs into comfortably adapting to their new surroundings. While memories of war and trauma from the refugee experience may continue to impact the settlement and integration experience of GARs, the RAP aims to provide refugees with an opportunity to re-establish their lives.

Q: So what was the role of the RAP program? If you came to Canada and the RAP program wasn't there how...

R: It was going to be difficult very very difficult. We are learned people in Kenya and were assisted by the RAP program. Instead we would go through problems like these. Then what about those who came here and who did not know the language...How did they manage? I feel sorry for people who came before us. I feel sorry for people who did not have this RAP... [Western Africa, Former GAR]

Participants also emphasized that while the RAP follows a supportive framework and a client centered approach, there is always room for improvement. Informants suggested that RAP services should not only be available to aid the immediate settlement of GARs, but should also provide long term coaching, counseling, and advocacy. The informants also acknowledged that GARs are resettled in Canada after undergoing violence, war, and being uprooted more than 
once. As such, informants suggested that the therapeutic supports and services necessary for high needs clients' must continue following the six week settlement period.

Sometimes people need help that you cannot see and identify. There was a friend of mine who through a translator, spoke to a family. And the family had seen their daughter get raped...I mean these people may seem normal but they may need help. How are they going to excel or get past it? I guess assigning that one person to the family would be well knowledged with all these areas. Really trying to pick out the needs... [and] talk to them. [Middle East, Former GAR]

As per their experience in working with newcomers, informants reported that refugees are less settled then other immigrant groups such as family sponsorship or the business class. However, between GARs and refugee claimants, GARs are provided with the timely, tools necessary for settlement and long term integration. Furthermore, after gaining Convention refugee status, former refugee claimants remain detached from support services and referrals to appropriate programs.

I would say in most cases why they lack or why they are behind is because in cases of refugee claimants, it's because they don't have access to services. In some cases for both refugee claimants and when later on they become Convention refugees and it's pretty much because of the way [in which] they came to Canada. But again some traumas and family circumstances and people left behind and all of that affects them emotionally and kind of keeps them back from accelerating. [Eastern Europe, Former GAR]

All four informants emphasized the positive effects of providing timely services and supports for refugees. Participants added that timely settlement services provide all newcomers with vital information. This information serves an important role in the immediate settlement as well as establishing long term goals. Informants felt that GARs received such services while refugee claimants did not. Refugee claimant's status was reported to be the cause of ineligibility for services.

...in refugee claimants' case most of these services would not be available to them...because they would be deemed as we call them, 
not we call them but the government funding sources calls them ineligible. So and as long as they cannot access these [services]... in a timely manner everything becomes more difficult and most cases you don't see any...progress [of] how those refugees who access settlement services has made towards those who cannot access services it is different. The outcomes, not only in employment but otherwise are different between the two...

[Eastern Europe, Former GAR]

Informants were also adamant about the fact that many, approximately sixty $(60)$ percent, of inlandasylum seekers are granted convention refugee status and remain in Canada (IRB, 2009). Participants felt that further attention needs to be paid to the transition from immediate settlement to the long term integration of refugee claimants.

I am aware that refugee claimants don't get services and I try to understand the government's perspective...the statistics of government most of them [refugee claimants] or above $60 \%$ get accepted. The question is... is the government wise not to provide services for that body of newcomers who will become citizens and why not provide services right away and have them start well. So that is why I ... services for refugee claimants I have a fixation about that. I feel like they are not sufficient and they are not provided on a timely manner and etcetera. In terms of government assisted refugees, we do have services a lot of services that are going on for them, not to say that there is no room for improvement. Of course there is room for improvement. [Eastern Europe, Former GAR]

Informants also provided insight into the different ways in which the Canadian immigration system can be altered to provide equal footing for refugee claimants, while they wait for their claims to process. The suggestion here was to adopt policies similar to the United States, where refugee claimants are provided appropriate documentation, social security information, work and education permits upon claiming convention refugee status. In this instance, although the claim may take years to process, refugee claimants are able to work and attend schools. The informant also added that the greatest barrier to transitioning into the labour force was the lack of bridging programs for professionals educated abroad. The informant suggested that the Canada needs to ensure that foreign qualifications are recognized. 
I think Canada needs to be more like the United States to recognize international qualifications. It needs to recognize that this is what you came with and you are good at what you do. Tell us what you can do and you are going to do it. The process is very smooth. If Canada could copy that it would be very good. They recognize international qualifications and they make it easy for the qualifications to be recognized. [Southern Africa, Former Refugee Claimant]

Other informants were also concerned that credential recognizing bodies as well as Canadian employers have contributed to the devaluation of foreign credentials and foreign experience. Participants argued that skilled newcomers, including refugees, have to work physical labour driven jobs or work with little specialized skills due to credential barriers. Meanwhile, these new Canadians are highly skilled professionals who have great plenty to contribute in the workforce.

...with no intention of generalizing ... if you are of South Asian background, Indian or Pakistani or Somali, most likely you are going to drive cab. Should that be the case though? Because most of those people come highly knowledgeable with huge experience... we know that their schools are run by professors from US or Great Britain and the study of language is English. So...knowing that the [Canadian] labour market is fluctuating, I think that communities or cities can do a better job in having strategies to better absorb the newcomers in the labour market. [Eastern Europe, Former GAR]

While the participants were eager to share their concerns they were also adamant about expressing their frustrations. Three of the informants reported that institutional and structural barriers which prevent new Canadians from gaining meaningful employment systematically inhibit the economic integration of immigrants. Informants also suggested that the barriers preventing newcomers from entering professional occupations do not only prevent newcomers from reaching their full potential, but also their communities. Participants made the case that the Canadian economy and local communities are not able to benefit from the diverse set of professional experiences which newcomers have to offer.

Q: Having worked with newcomers and particularly refugees for many years, do you think that refugees are successful in Canada? 
R: No... the system is not created for us to be successful. The system is created for us to do mundane jobs. To be sweepers and cleaners and street people. You know what I'm saying? And when you think of how old you are and how much time... and family responsibilities ... how are you going to start? I think that the government of Canada created it that way because they are not looking for educated people... They are not looking for people like me, they are looking for people... who come into this country and working the factories as cheap labour. [Southern Africa, Former Refugee Claimant]

While informants did attribute the difficulties faced by immigrants to institutional barricrs, informants also reported that discrimination and racism are elements which further contribute to the inability of refugees to transition into the workforce. All four participants addressed issues of discrimination and racism within the work environment.

I suffered amazing, and debilitating racism... it wasn't just from the fellow employees it was from Canadians themselves. One Canadian male came to me and said why are you working here you should be outside there telling little black boys not to dress like that and not to be in gangs. [Southern Africa, Former Refugee Claimant]

She's involved now but she's had a hard time finding a job.... she's good but because of the accent they would rather hire a younger girl who is fluent. [Middle East, Former GAR]

...your own workers, they look down on you. They do anything to get you out of your job, they will lie on you. Yes the treatment is different. They make us clean the heavy patients. That was surely discrimination. [Western Africa, Former GAR]

...new immigrants coming from [European backgrounds]... even though you have less and less of those...they tend to do better than the immigrants coming from visible minority origins. Although if you talk to individual immigrants such as myself, my story was no different than any other story of any refugee that I have worked with. I tend to believe that social structures play a huge role there. And I can tell ...especially lately that people have the tendency to look at immigrants with a certain level of suspicion. And that for sure hinders their success rating with respect to employment or education or you name it. [Eastern Europe, Former GAR] 
Although all four informants shared experiences of discrimination within the workplace, the former refugee claimant reported that both the racism and discrimination was caused by the participants' status as a refugee claimant. The participant suggested that this status enabled the co-workers and Canadian born clients to discriminate against the participant and assume prejudicial inequality. For this participant, permanent residency or Canadian citizenship were seen as mediums which could guarantee the rights and equality of immigrants similar to those of Canadian born.

...the US [gives] you the paper work that makes you even and equal with everyone else. Even though you are still waiting for your papers and what not, they give you what you need to go out there and do what you got to do. So they give you access to equal opportunities as everybody else...If Canada could do that it would be...because lots of refugee claimants they come to a new country with new ideas and dreams. [Southern Africa, Former Refugee Claimant]

However, former GAR informants reported that the discrimination they faced was due to their recent transition into the workforce. Former GARs shared that initially, elements such as their accents or lack of Canadian experience contributed to ill treatment in the workforce. However, former GARs became more empowered when they learned about their rights and responsibilities in the workplace. Their ability to defend their rights assisted them in securing their current positions and working with confidence. 


\section{Discussion}

The findings of this research project provide a wide ranging account of the refugee settlement and resettlement experience in Canada. This section will discuss the most salient themes which have emerged from the interviews. In analyzing the rich experiences and expertise contributed by research participants, this project has been able to tap into the lived experiences of participants on two levels. First, informants have been able to share personal insight from their own settlement and resettlement processes in Canada. Second, participants have been able to contribute insight, as professionals and key informants, into the immigration and settlement experiences of other refugees in Hamilton. The informants contributed an invaluable array of suggestions, expertise, and experiences. It is also important to note that the research participants continue to advocate for all newcomers, including refugees, in their professional capacities and as grassroots activists.

One of the most significant findings of this research project is directed at the effects of the refugee experience and immediate settlement experiences on the long term integration of refugees in Canada. Both former GARs and the former refugee claimant provided in depth accounts of their refugee experiences and the ways in which such experiences shaped their expectations and readiness for life in Canada. All four participants underwent crisis situations which included; civil war for two participants, political persecution for one participant and religious persecution for another participant. Participants paid smugglers to cross borders in two of the four cases. In three of the four interviews, informants reported that they were required to pass through more than one country to safely wait for the refugee determination process. All of the aforementioned experiences exposed participants to traumatic stress which continued to affect their emotional and mental wellbeing after arrival to Canada. The three former GAR 
participants demonstrated a certain level of ease after arrival to Canada due to the timely supports, services and referrals which were provided by RAP. In describing their immediate settlement experiences, former GARs emphasized that they were at ease during their first year in Canada. These three participants highlighted that they had the opportunity to adapt to life in Canada. The RAP provided former GARs with timely information, referrals to other agencies, and facilitated their contact with various ethno-cultural and religious organizations. Overall, the former GARs were very informed about the healthcare, transportation, and educational systems in Canada.

While interviews with former GARs indicated that they were well equipped to begin their integration process, the former refugee claimant continued to face stressful situations upon arriving to Canada. Ineligibility to settlement services, inadequate supports, lack of credible information, and experiences of discrimination posed as barriers to adapting to life in Canada.

Q: If you had the authority and power to change some major things. In terms of refugee claimants, once receiving convention refugee status, what you would do to change their outcomes?

R: I would make the resources that are available to government assisted refugees also available to refugee claimants...should be available to refugee claimants. I mean that is the least the government of Canada can do. This is my opinion. Because when you walk through that border, they are taking responsibility for your wellbeing. Which is different from the US. They give you everything you need and say, you are on your own bye bye. [Southern Africa, Former Refugee Claimant]

The former refugee claimant reported that the largest contributor to her success in Hamilton was that she resided in the United States prior to immigrating to Canada. The informant shared that the linguistic, cultural, and institutional similarities between the countries prepared her for the challenges ahead. The informant also shared that had she not been exposed to the lifestyle in the US, as a refugee claimant she would have struggled much more. 
Coming from the US helped me a lot. It gave me a cushion and at work they would acknowledge America. It makes me think of that refugee who comes straight from Africa or who comes straight from the Middle East who does not have [this experience]... [Southern Africa, Former Refugee Claimant]

Similar to Morton Bieser's (1999) work, the research findings indicated that the initial settlement experiences were crucial in shaping the settlement and long term integration of refugees in Canada. Beiser (1999) suggests that “...each newcomer to Canada develops his or her new unique pattern of integration, balancing past with present to create a synthesis of attitudes, skills and vision of future that is useful to the individual" (Beiser, 1999, pp. 150). As a result, refugees who have access to supports, advocacy, and services are able to make more informed decisions about their future goals and aspirations. Meanwhile, refugee claimants who do not have access to timely support and services are individuals who are at risk of isolation (Beiser, 1999; see also Lacroix, 2004). For these refugees, the ineligibility to services lengthens the settlement process and hinders their long term economic integration. The largest obstacles faced by the former refugee claimant upon arrival were the barriers posed by her status. The former refugee claimant was neither able to attend post secondary institutions nor gain meaningful employment during the 'legal limbo' period (Lacroix, 2004) As investigated by Lacroix (2004) and Renaud \& Gingras (1998) refugee claimants may very well find access to jobs in Canada after having spent three or more years in Canada (Lacroix, 2004).

One of the principal ways in which the experiences of the three former GARs and one former refugee claimant deferred pertains to the availability of the formally administered RAP. The RAP was able to alleviate the frustration and stress associated with initial settlement in Canada. The program provided the informants with a support system, information, and guidance. The former GAR informants often returned and sought assistance or information from RAP staff after the 12 to 24 month period. Overall, RAP's contributions to the resettlement process of 
former GAR were plentiful. The program worked to alleviate the immediate and long term pressures of settlement. The program contributed to a comparatively positive immediate settlement experience for former GARs. These timely services allowed former GARs to adapt to life in Canada while the former refugee claimant continued to struggle. The former refugee claimant also expressed her frustrations and reported that it was her own persistence, knowledge of the country, and previous experiences which allowed her to maneuver various systems. The lack of timely services increased her stress and she was required to gain access to information by herself. In the case of the former refugee claimant, the absence of extended family members further marginalized her and contributed to a negative immediate settlement expcrience.

The RAP did not only play a positive role on the immediate settlement and long term integration of former GARs, but the program also mitigated against systematic and structural barriers which otherwise restrict or limit the economic and overall integration of refugees. The RAP provided former GARs with the tools, in the form of timely services, necessary to maneuver various institutions and systems. Such tools included, but were not limited to, direct referrals and information sessions. It is argued that the RAP, itself a federally funded government program, was able to alleviate and mitigate the barriers posed by other institutions such as credential recognizing bodies or professional organizations.

One informant thoroughly shared his expert opinion on the benefits of timely services for refugee claimants and GARs.

[I was told] that if you have finished university back home, you will be able to do that again here. And that was kind of at that moment, momentum. It was a moment for me that made me believe that I can do things again that I have done before. That is what some of these services they do for the settlement of newcomers...still those information that you get from settlement services and most definitely through the RAP program at some point translate to positive outcomes and they enhance future 
employment outcomes... once you provide services, timely services and lets say in the case of the GARs for the first six months or one year... most likely they will produce positive outcomes in terms of employment at some point. Why? Because if you have that support right from the beginning from the RAP program or any other settlement program you would be more informed. You would feel that you are supported and that you can do things. Sometimes these programs, all they do for certain individuals is convince them... not that they convince them... settlement professionals they work with a clients to regain that confidence that they can do things the way they did before... because don't forget that most of GARs or immigrants or refugee claimants for that matter, they are people who had their jobs and they had their families and they had their regular everyday lives. Once they come here for any of those reasons like war and displacement and etcetera, there's a feeling that they have lost all of that. [Eastern Europe, Former GAR]

Since "the number of refugee arrivals has stabilized at fewer than 25,000 per year, roughly ten percent of the immigrant [arrivals to Canada]", it is imperative to ask how refugees fare in the Canadian labour force (DeVoretz et al., 2004, pp. 2). It is therefore important to examine the tools used by the two refugee groups to transition into the workforce. This section of the discussions will attempt to provide an assessment of the different tools used by participants to transition into the Canadian workforce. Similar to the findings of Beiser (1999), the informant's interviews demonstrated that “...the longer refugees stayed in Canada, the more selfsufficient they became..." (Beiser, 1999, pp. 178; see also DeVoretz, 2004; DeSilva, 1997). Interestingly, while refugee experiences and immediate settlement experiences of participants were distinct to refugees, the tools used by both former GARs and the former refugee claimant informant to transition into the workforce were similar to the techniques used by skilled immigrants.

While, the greatest differences between former GARs and the former refugee claimant participant were discovered when discussing their immediate settlement experiences, it is clear that most informants shared similar educational and professional backgrounds in their country of 
origin. Three of the informants completed secondary school and university degrees in their country of origin. All three of these participants undertook extensive professional and further educational training within their professional fields in their country of origin. Having experienced the process of gaining secondary and post secondary education, the informants had a good understanding of social and cultural competencies within educational systems. While some refugees remain outside of formal educational systems for years, the research participants in this project were not only extensively exposed to the school and university environments, but they held highly prestigious occupational positions. The three informants who came to Canada with previous educational and professional experience reported that previous knowledge and professional experience played pivotal roles in their successful settlement and long term integration. Furthermore, informants shared that their previous educational backgrounds assisted them in understanding the ways in which institutional structures such as educational systems, service provider organizations, healthcare systems, housing or taxing systems operated in Canada. Informants were aware of interview processes, the significance of resumes, and various job searching techniques. Similar to skilled immigrants, participants' educational achievements coupled with their professional experience from their countries of origin provided the informants with the human capital, necessary to successfully transition into the workforce in Canada.

Such findings were parallel to the findings of Ferrer and Riddell (2008) who found that although skilled immigrants receive lower returns to years of schooling than do Canadians, immigrants' credentials were useful and valued in Canada (Ferrer \& Riddel, 2008; see also Girard et al., 2010). Relative to newcomers without post-secondary degrees, skilled immigrants who completed foreign educational programs received earning gains (Ferrer \& Riddell, 2008). In 
this instance, the foreign education and professional experience acquired by refugees and skilled immigrants had similar, positive, effects on their labour market outcomes.

Most importantly, the former refugee claimant and former GARs understood and acknowledged the benefits of volunteering. Three of four participants began voluntecring at local organizations within two years of their arrival. The remaining participant was too young to volunteer and attended elementary school. However, this participant's parents also began volunteering within two years of their arrival to Canada. All four informants explained that volunteering provided them with an opportunity to further learn about the Canadian culture, community resources which are available, and professional competencies. Similar to the findings of Kelly Ng (1993), volunteering facilitates the "[immigrant] involvement as volunteers in the mainstream society" (Ng, 1993, pp. 32). While Ng's (1993) research findings suggested that volunteering assisted in the settlement outcomes of Chinese immigrant women, this study finds that volunteering was used as a tool to transition into the workforce. This research project found that two of three participants, who were of working age upon settling in Canada, found employment within the social service sector as counselors and administrative assistants. These participants suggested that it was their volunteer experience which provided them enough exposure and familiarity within the social service sector. This familiarity translated to confidence and empowerment which led the informants to apply for positions and secure employment.

The informants were also adamant about discussing the guidance, support and information they received from their social networks. As such, this paper will differentiate between different types of social networks. Subsequently, we will provide a thorough analysis of the ways in which social networks facilitated the transition of the informants into their current professions. 
There is an abundance of research which addresses the effects of social networks on immigrant settlement, emotional wellbeing, employment outcomes, and more (Matthews et al, 2009; see also Lamba, 2003; Zietsma, 2010; Ryan et al, 2008; Xue, 2008 Delattre \& Sabatier, 2004; Wahba \& Zenou, 2005). Most, if not all, of the research projects have thoroughly differentiated between various forms of social capital. Such distinctions between types of social capital often aim to categorize social capital based on the degree and significance of social interactions. Putnam (2007) and Ryan et al (2008) make a distinction between "...bonding 'ties to people who are like me in some important way', and bridging 'ties to people who are unlike me in some important way'..." (Putnam, 2007; as cited in Ryan et al, 2008, pp. 676). Meanwhile, Xue's (2008) work suggests that the size of social networks is also a significant variable to consider (Xue, 2008).

Interviews carried out with all four informants supported the notion of social capital translating to and contributing to the economic outcomes of immigrants. Similar to the findings of Beiser (1999) “...regular contact with Canadians in the majority culture...and relationships that extend beyond ethnic boundaries" were used as tools to transition to the workforce and participate in the Canadian society (Beiser, 1999, pp. 180). More specifically, informants participated in the Canadian society by securing employment. An important distinction was made by the informants between the utility of two different types of social capital. Similar to Lamba's (2003) research, while the existence of relationships with members of informants' own ethno-cultural communities provided refugees with emotional support, relationships beyond their ethno-cultural communities with mainstream Canadians were used for professional networking purposes (Lamba, 2003; see also Dorantes \& Mundra, 2004). Affiliations with one participants' religious community did lead to professional advancement. However, this participants' religious 
community consisted of a diverse congregation whose members were from a wide range of ethno-cultural, newcomer, and mainstream communities. Such findings were consistent with research which was carried out on skilled immigrants' labour market outcomes by Matthews, Pendakur \& Young (2009) (Matthews et al., 2009; see also Xue, 2008; Woolcock, 2000; Stone et al, 2003).

While volunteering and professional networking were useful tools, informants reported that enrolment in post secondary educational institutions such as colleges or universities were essential in securing professional positions. Informants shared that their efforts in furthering their educational aspirations in Canadian universities or colleges gave them a competitive edge when seeking employment. Three of four participants had a university degree from Canada and one participant was working towards the completion of the degree. The participant who was completing their university degree had already acquired a college diploma in Canada. Volunteering, networking with other professionals, coupled with gaining a degree or diploma ensured a successful transition into professional occupations. Such research findings on the benefits of education are similar to those of Girard, Smith \& McGill (2010) who concluded that access to regulated occupations increases with additional levels of education. Ferrer and Riddell (2008) also found that the human capital of immigrants who completed their education in Canada is rewarded in the Canadian economy.

However, none of the three tools restored the informants' previous professional status or prestige from their country of origin. Such findings also concur with contemporary research on the labour market outcomes of immigrants. Although immigrants, including refugees, have a greater advantage in terms of measured human capital, they are often underemployed or work in 
unregulated professions (Ferrer \& Riddel, 2008; see also Wald \& Fang, 2008; Reitz, 2005; Orcopoulos, 2009; Mata, 2008; Hiebert, 2009; Girard et al, 2010).

Research participants have shared an abundance of valuable expertise. Both former GARs and the former refugee claimant's experiences have contributed to the creation of an intimate glimpse into the realities of being a refugee in Canada. Truly, while the policy framework aims to provide holistic regulations and procedures, the lived human experience indicates that there are plenty of gaps in the provision of services for inland refugees. With respect to transitioning into the Canadian workforce, the findings clearly indicate that increased attention needs to be paid to highly skilled refugees, both GARs and refugee claimants. The provision of timely services, including employment and professional training services, for refugees will translate to greater entrance into regulated professions. 


\section{Recommendations}

\begin{tabular}{|c|c|c|c|c|}
\hline \multicolumn{5}{|c|}{ Receiving a 'Welcome to Canada' upon arrival to the country } \\
\hline $\begin{array}{r}\text { GOVERNME } \\
\text { REF }\end{array}$ & $\begin{array}{l}\text { T ASSISTED } \\
\text { JEES }\end{array}$ & RE & UGEE CLAIMAN & TS \\
\hline $\begin{array}{l}\text { Current } \\
\text { Services }\end{array}$ & Benefits & $\begin{array}{l}\text { Current } \\
\text { Services }\end{array}$ & $\begin{array}{l}\text { Recommended } \\
\text { Services }\end{array}$ & Benefits \\
\hline $\begin{array}{l}\text { GARs receive a } \\
\text { welcome by RAP } \\
\text { staff upon arrival to } \\
\text { Canada. } \\
\text { RAP staff greet } \\
\text { GARs at the airport } \\
\text { in an accessible } \\
\text { language. }\end{array}$ & $\begin{array}{l}\text { GARs remember } \\
\text { their first moments } \\
\text { in Canada and this } \\
\text { contributes to a } \\
\text { positive arrival } \\
\text { experience. }\end{array}$ & $\begin{array}{l}\text { Non-GAR refugees } \\
\text { must independently } \\
\text { declare their } \\
\text { intentions to claim } \\
\text { asylum to a local } \\
\text { CIC office. } \\
\text { They are given PIF } \\
\text { applications which } \\
\text { must be completed } \\
\text { and returned in } 28 \\
\text { days. }\end{array}$ & $\begin{array}{l}\text { Upon initial contact } \\
\text { with CIC } \\
\text { staff/officers, } \\
\text { refugees intending } \\
\text { on claiming asylum } \\
\text { must receive an } \\
\text { official 'Welcome to } \\
\text { Canada'. } \\
\text { Local CIC } \\
\text { staff/officers must } \\
\text { have a current } \\
\text { understanding of the } \\
\text { services and } \\
\text { supports available to } \\
\text { refugee claimants in } \\
\text { the city. } \\
\text { Upon initial contact } \\
\text { with CIC } \\
\text { staff/officers, } \\
\text { appropriate and } \\
\text { current settlement } \\
\text { information needs to } \\
\text { be given to refugee } \\
\text { claimants. }\end{array}$ & $\begin{array}{l}\text { This small gesture } \\
\text { will continue to } \\
\text { shape their } \\
\text { immediate } \\
\text { settlement in } \\
\text { Canada, given that } \\
\text { on average, } 60 \% \text { of } \\
\text { refugee claimants } \\
\text { are granted } \\
\text { convention refugee } \\
\text { status. } \\
\text { Upon receiving } \\
\text { Convention Refugee } \\
\text { status, former } \\
\text { refugee claimants } \\
\text { are well equipped to } \\
\text { maneuver various } \\
\text { institutional systems. } \\
\text { Upon receiving } \\
\text { Convention Refugee } \\
\text { status, former } \\
\text { refugee claimants } \\
\text { are settled in Canada } \\
\text { and equipped to } \\
\text { further integrate. }\end{array}$ \\
\hline
\end{tabular}




\begin{tabular}{|c|c|c|c|c|}
\hline \multicolumn{5}{|c|}{ Receiving information sessions upon arrival to the country } \\
\hline \multicolumn{2}{|c|}{$\begin{array}{c}\text { GOVERNMENT ASSISTED } \\
\text { REFUGEES }\end{array}$} & \multicolumn{3}{|c|}{ REFUGEE CLAIMANTS } \\
\hline $\begin{array}{l}\text { Current } \\
\text { Services }\end{array}$ & Benefits & $\begin{array}{l}\text { Current } \\
\text { Services }\end{array}$ & $\begin{array}{l}\text { Recommended } \\
\text { Services }\end{array}$ & Benefits \\
\hline $\begin{array}{l}\text { GARs receive in } \\
\text { depth information } \\
\text { sessions within } 10 \\
\text { days of arrival on } \\
\text { their legal rights and } \\
\text { responsibilities, the } \\
\text { healthcare system, } \\
\text { Canadian currency } \\
\text { and budgeting, } \\
\text { housing rights and } \\
\text { responsibilities, } \\
\text { educational system, } \\
\text { referral to } \\
\text { employment services } \\
\text { and more. }\end{array}$ & $\begin{array}{l}\text { Although this } \\
\text { process is fast } \\
\text { tracked, the } \\
\text { information GARs } \\
\text { obtain is accurate } \\
\text { and ensures that } \\
\text { families and } \\
\text { individuals make } \\
\text { well informed } \\
\text { choices while } \\
\text { adapting to life in } \\
\text { Canada. }\end{array}$ & $\begin{array}{lr}\text { Refugee } & \text { claimants } \\
\text { are not provided } \\
\text { with orientation } \\
\text { sessions } \\
\text { settlement services } \\
\text { by CIC. } \\
\text { Refugee claimants } \\
\text { are not eligible for } \\
\text { most, if not all, } \\
\text { settlement services } \\
\text { provided by SPOs. }\end{array}$ & $\begin{array}{l}\text { Non-GAR refugees } \\
\text { must be provided } \\
\text { with information } \\
\text { sessions pertaining } \\
\text { to: } \\
\text { 1. Their rights and } \\
\text { responsibilities as } \\
\text { refugee claimants } \\
\text { 2. The refugee } \\
\text { protection } \\
\text { process, rules, } \\
\text { regulations and } \\
\text { what to expect } \\
\text { 3. Housing } \\
\text { regulations } \\
\text { Canada, } \\
\text { accessing social } \\
\text { assistance, and } \\
\text { educational } \\
\text { programs } \\
\text { 4. How to apply for } \\
\text { permanent } \\
\text { residency; what } \\
\text { are the required } \\
\text { documents; how } \\
\text { long will the } \\
\text { process take } \\
\text { While the } \\
\text { information sessions } \\
\text { provided to refugee } \\
\text { claimants do not } \\
\text { have to be as } \\
\text { rigorous nor as } \\
\text { exhaustive as those } \\
\text { provided to GARs, } \\
\text { they must address } \\
\text { institutional } \\
\text { frameworks or } \\
\text { processes which } \\
\text { refugee claimants } \\
\text { will be confronted } \\
\text { with. }\end{array}$ & $\begin{array}{l}\text { The refugee } \\
\text { determination } \\
\text { process will be } \\
\text { understood by } \\
\text { refugee claimants. } \\
\text { Refugee claimants } \\
\text { will be more } \\
\text { informed about their } \\
\text { rights and } \\
\text { responsibilities } \\
\text { while their status is } \\
\text { determined. } \\
\text { Refugee claimants } \\
\text { will make more } \\
\text { informed decisions } \\
\text { when addressing } \\
\text { their housing, } \\
\text { economic, and } \\
\text { educational needs. } \\
\text { Informed refugee } \\
\text { claimants will } \\
\text { contribute to a faster } \\
\text { refugee } \\
\text { determination } \\
\text { system. } \\
\text { Informed convention } \\
\text { refugees will be able } \\
\text { to apply for } \\
\text { permanent residency } \\
\text { with ease. } \\
\text { Informed convention } \\
\text { refugees will be able } \\
\text { to understand the } \\
\text { institutional } \\
\text { framework available } \\
\text { to them for their } \\
\text { settlement needs. }\end{array}$ \\
\hline
\end{tabular}




\begin{tabular}{|c|c|c|c|c|}
\hline \multicolumn{5}{|c|}{ Receiving employment support services upon arrival to the country } \\
\hline \multicolumn{2}{|c|}{$\begin{array}{l}\text { GOVERNMENT ASSISTED } \\
\text { REFUGEES }\end{array}$} & \multicolumn{3}{|c|}{ REFUGEE CLAIMANTS } \\
\hline $\begin{array}{l}\text { Current } \\
\text { Services }\end{array}$ & Benefits & $\begin{array}{l}\text { Current } \\
\text { Services }\end{array}$ & $\begin{array}{l}\text { Recommended } \\
\text { Services }\end{array}$ & Benefits \\
\hline $\begin{array}{l}\text { GARs become } \\
\text { permanent residents } \\
\text { upon arrival and } \\
\text { have access to most } \\
\text { settlement services } \\
\text { including HOST, } \\
\text { ISAP, LINC and } \\
\text { employment } \\
\text { programs. } \\
\text { RAP refers GARs to } \\
\text { settlement agencies } \\
\text { and facilitates their } \\
\text { introduction to } \\
\text { various employment } \\
\text { programs to direct } \\
\text { referrals. } \\
\text { As a result, GARs } \\
\text { are able to access } \\
\text { employment } \\
\text { searching, resume } \\
\text { writing, mentorship } \\
\text { programs, as well as } \\
\text { accessing credential } \\
\text { recognizing and } \\
\text { accreditation bodies. }\end{array}$ & $\begin{array}{l}\text { GARs are able to } \\
\text { access the tools } \\
\text { necessary to } \\
\text { transition into the } \\
\text { Canadian labour } \\
\text { market. } \\
\text { GARs are able to } \\
\text { contribute to the } \\
\text { Canadian economy. } \\
\text { GARs are able to } \\
\text { better strategize and } \\
\text { create long term and } \\
\text { short term goals. } \\
\text { GARs are able to } \\
\text { quickly access } \\
\text { educational } \\
\text { programs if needed. }\end{array}$ & $\begin{array}{l}\text { Refugee claimants } \\
\text { are not eligible for } \\
\text { professional } \\
\text { development } \\
\text { programs and } \\
\text { services. }\end{array}$ & $\begin{array}{l}\text { Employment } \\
\text { programs and } \\
\text { services must be } \\
\text { available to } \\
\text { permanent residents, } \\
\text { refugee claimants, } \\
\text { convention refugees, } \\
\text { and citizens. } \\
\text { Employment } \\
\text { programs empower } \\
\text { all newcomers, and } \\
\text { facilitate their } \\
\text { successful transition } \\
\text { into the workforce. }\end{array}$ & $\begin{array}{l}\text { Eligibility to access } \\
\text { employment } \\
\text { programs will } \\
\text { provide an endless } \\
\text { array of benefits for } \\
\text { all refugees educated } \\
\text { abroad. } \\
\text { 1. Cost effective } \\
\text { employment } \\
\text { programs will } \\
\text { ensure that } \\
\text { foreign educated } \\
\text { professionals } \\
\text { who are refugees } \\
\text { are aware of the } \\
\text { opportunities } \\
\text { available to them } \\
\text { in Canada, } \\
\text { pending the } \\
\text { determination of } \\
\text { their status. } \\
\text { 2. Convention } \\
\text { refugees awaiting } \\
\text { permanent } \\
\text { residency will } \\
\text { benefit by } \\
\text { actively } \\
\text { searching for } \\
\text { employment, } \\
\text { beginning their } \\
\text { degree } \\
\text { accreditation } \\
\text { processes, } \\
\text { volunteering or } \\
\text { participating in } \\
\text { professional } \\
\text { mentorship } \\
\text { programs. } \\
\text { A larger portion of } \\
\text { former refugee } \\
\text { claimants will be } \\
\text { able to enter } \\
\text { regulated } \\
\text { occupations or } \\
\text { similar professional } \\
\text { fields }\end{array}$ \\
\hline
\end{tabular}




\section{Bibliography}

Bhabha, J. (2005) 'Trafficking, Smuggling, and Human Rights'. Migration Information Source: Fresh Thought, Authoritative Data. Global Research on Migration Policy Institute. Retrieved October $25^{\text {th }}, 2010 \mathrm{http} / /$ www.childtrafficking.com/Docs/migration funda 1007.pdf

Beiser, M. (1999) 'Chapter 9 - Profiles of Success'. Strangers at the Gate: The 'Boat Peoples' First Ten Years in Canada. Pp. 146. Univeristy of Toronto Press. Toronto, ON, Canada.

Beiser, M. (1999) 'Chapter 10 - Please See Screaming'. Strangers at the Gate: The 'Boat Peoples' First Ten Years in Canada. Pp. 178. Univeristy of Toronto Press. Toronto, ON, Canada.

Bilger, V., M. Hofmann \& M. Jandl. (2006) 'Human Smuggling as a Transnational Service Industry: Evidence from Austria'. International Migration. 44(4).

Brunner, L. R., J. Hyndman, \& C. Friesen. (2010) 'Aceh-Malaysia-Vancouver: Settlement Among Acehnese Refugees Five Years On'. Metropolis British Columbia. Working Paper Series.

Citizenship and Immigration Canada (2002) 'A Statistical Profile of Government-Assisted Refugees'. SRDC. http://www.srdc.org/uploads/statistical_profile.pdf Retrieved on April 21st, 2011.

Citizenship and Immigration Canada (2007) 'Backgrounders - 2007'. Citizenship Immigration Canada http://www.cic.gc.ca/english/department/media/backgrounders/2007/2007-06-20.asp Retrieved on February $20^{\text {th }}, 2011$.

Citizenship and Immigration Canada (2007) 'Annual Report to Parliament on Immigration'. Citizenship and Immigration Canada. http://www.cic.gc.ca/english/resources/publications/annual-report2007/index.asp $\quad$ Retrieved February 14th, 2011.

Citizenship and Immigration Canada (2010) 'In Canada Processing of Convention Refugees Abroad and Members of the Humanitarian Protected Persons Abroad Classes'. IP3. http://www.cic.gc.ca/english/resources/manuals/ip/ip03-part4-eng.pdf Retrieved on Maylst, 2011.

Citizenship and Immigration Canada (2011) 'Evaluation of Government Assisted Refugees (GAR) and Resettlement Assistance Program (RAP)'. Final Evaluation Report. http://www.cic.gc.ca/english/resources/evaluation/rap-summary.asp Retrieved on June 27 th, 2011.

Danso, R. (2002), 'From 'there' to 'here': An Investigation of the Initial Settlement Experiences of Ethiopian and Somali refugees in Toronto'. GeoJournal 56(1). Pp. 3. 
Dawson, C. (2011) 'On Thinking Like a State and Reading (about) Refugees'. Journal of Canadian Studies. 45(2). Pp. $58-75$.

Debeljacki, M. J. (2007) 'GARs in Toronto's LINC Classes: An Exploration of Perceived Needs and Barriers'. Major Research Paper for Ryerson University. ProQuest LLC. Paper 109.

Delattre, E. \& M. Sabatier. (2004). 'Social Capital and Wages: An Econometric Evaluation of Social Networking Effects'. www.aiel.it/bacheca/MODENA/PAPERS/Delattre Sabatier.pdf November $25^{\text {th }}, 2010$.

Dietz, J., V. M. Esses, C. Joshi, \& C. B. AbuAyyash. (2009). 'The Evaluation of Immigrants' Credentials: The Roles of Accreditation, Immigrant Race, and Evaluator Biases'. Canadian Labour Market and Skills Researcher Network (CLSRN).

DeSilva, A. (1997) 'Earnings of Immgirant Classes in the Early 1980s in Canada: A Reexamination'. Canadian Public Policy. 23(2). Pp. 179-202.

DeVoretz, D, S. Pivnenko \& M. Beiser (2004) 'The Economic Experiences of Refugees in Canada'. Institute for the Study of labor (IZA) Discussion Paper No. 1088. http://ssm.com/abstract=526022. March $1^{\text {st }}, 2011$.

Dorantes, C. \& K. Mundra. (2005). 'Social Networks and their Impact on the Employment and Earnings of Mexican Immigrants'. EconWPA Labour and Demography Working Paper0502001. San Diego State University, Department of Economics. http://129.3.20.41/eps/lab/papers/0502/0502001.pdf December 1st, 2010

Ferrer, A. \& W. C. Reddell (2008). 'Education, Credentials, and Immigrant Earnings". Canadian Journal of Economics, 41 (1). Pp. 186-216.

Girard, M., M. Smith \& J. McGill (2010). 'Working in a Regulated Occupation in Canada: An Immigrant Native-Born Comparison'. CIC: Metropolis Project, Research Capsules: Select Expert Research on Foreign Credential Recognition in Canada. http://canada.metropolis.net/publications/index_e.htm. February 22nd, 2011.

Hiebert, D. (2009). 'The Economic Integration of Immigrants in Metro Vancouver'. Working Paper. Metropolis British Columbia: Centre of Excellence for Research on Immigration and Diversity. http://www.amssa.org/arc/search.php?q=\&themes $=6$. February $20^{\text {th }}, 2011$.

Hyndman, J. \& J. McLean (2006) 'Settling Like a State: Acehnese Refugees in Vancouver'. Journal of Refugee Studies, 19(3). Pp. 345.

Immigration Refugee Board (2009). 'Report: Roundtable on Inland Refugee Claimants'. Immigrant Sector Council of Calgary. Citizenship and Immigration Canada. 
Jayasinghe, U. \& S. Baglay. (2011) 'Protecting Victims of Human Trafficking Within a 'NonRefoulement' Framework: is Complementary Protection an Effective Alternative in Canada and Australia?' International Journal of Refugee Law. 23(3) Pp. 489-520.

Krahn, H., T. Derwing, M. Mulder \& L. Wilkinson (2000) 'Educated and Underemployed: Refugee Integration into the Canadian Labour Market'. Journal of International Migration and Integration. 1(1). Pp. 59-84.

Lacroix, M. (2004) 'Canadian refugee Policy and the Social Construction of the Refugee Claimant Subjectivity: Understanding Refugeeness'. Journal of Refugee Studies. 17(2). Pp. 149 $-166$.

Lamba, K. N. (2003) 'The Employment Experience of Canadian Refugees: Measuring the Impact of Human and Social Capital on Quality of Employment'. Canadian Review of Sociology 40(1). Pp. 45-64.

Mata, F. (2008). 'Exploring Linkages Between the Country of Post-Secondary Education Completion and Labour Market Activity of Immigrants in Canada'. Working Paper. Metropolis British Columbia: Centre for Excellence for Research on Immigration and Diversity. http://www.anssa.org/arc/search.php?q=\&themes=6. February $28^{\text {th }}, 2011$.

Matthews, R., R. Pendakur \& N. Young (2009) 'Social Capital, labour Markets, and Job Finding in Urban and Rural Regions: comparing paths to employment in prosperous cities and stressed rural communities in Canada'. The Sociological Review. 57(2).

Michalski, J. H., \& Y. Habib (1997) 'A Study of Iraqi Refugees: Final report'. Joint Centre of Excellence for Research on Immigration and Settlement (CERIS): Centre for Applied Social Research, Faculty of Social Work, University of Toronto. http://ceris.metropolis.net/Virtual\%20Library/community/Iraqi michalski/frontpage.html Retrieved on February 22nd, 2011.

Mohamed, H. 2002. Neither Here Nor There: The Social Cost of Refugees in Limbo. INSCAN 15 , no. 3 (winter).

Mountz, A. (2004) 'Embodying the Nation-State: Canada's Response to Human Smuggling'. Political Geography. 23(3). Pp. 323-345.

Murdie, R., A. (2008) 'Pathways to Housing: The Experiences of Sponsored Refugees and Refugee Claimants in Accessing Permanent Housing in Toronto'. Journal of International Migration and Integration. 9(1). Pp. 81-101.

Navaratna, A. P. (2006) 'The Settlement Experience of Government Assisted Refugees in Hamilton, Ontario: A Critique of Canada's Refugee and Humanitarian Resettlement Program'. Major Research Paper for Ryerson University. ProQuest LLC. 
Ng, K. K. Y. (1993) 'Volunteer Work and Settlement: A Study of Chinese Immigrant Women'. The United Chinese Community Enrichment Services Society (SUCCESS). Canadian Journal of Community and Mental Health. 12(2). Pp. $31-44$.

Omidvar, R. \& T. Richmond. (2003) 'Immigrant Settlement and Social Inclusion in Canada'. Working Paper Series. Laidlaw Foundation. Toronto.

Oreopoulos, P. (2009). 'Why do Skilled Immigrants Struggle in the Labour Market? A Field Experiment with Six Thousand Resumes'. National Bureau of Economic Research. Working Paper 15036. http:/www.amssa.org/arc/search.php?q=\&themes=6. February $25^{\text {th }}, 2011$.

Power Analysis Inc. (2002). 'Evaluation of the Resettlement Assistance Program: Final Report'. http://settlement.org/downloads/Resettlement_Assistance Program Evaluation.pdf Retrieved on February 15 th, 2011.

Putnam, R. D. (2007) 'E Pluribus Unum: Diversity and Community in the Twenty-first Century'. Scandinavian Political Studies. 30(2). Pp. 137-174.

Public Safety Canada. (2010) Retrieved on October $21^{\text {st }} 2010$. http://www.publicsafety.gc.ca/hmn-smgglng-eng.aspxx

Presse, D. \& J. Thomson. (2008) 'Integration of Refugees from Protracted Refugee Situations'. Refuge. 24(2). Pp. 94-99.

Reitz, J. G. (2005). 'Tapping Immigrants' Skills.' New Directions for Canadian Policy in the Knowledge Economy 11(1). Pp. 2-18.

Renaud, J, V. Piché \& J. F. Godin. (2003) "One's Bad and the Other One's Worse': Differences in Economic Integration Between Asylum Seekers and Refugees Selected Abroad.' Canadian Ethnic Studies, 35 Pp. 86-99.

Rose, D. and B. Ray (2001). 'The Housing Situation of Refugees in Montreal Three Years after Arrival: The Case of Asylum Seekers who Obtained Permanent Residence.' Journal of International Migration and Integration, 2. Pp. 493-529.

Ryan, D., B. Dooley, \& C. Benson. (2008) 'Theoretical Perspectives on Post-Migration Adaptation and Psychological Well-Being Among Refugees: Towards a Resource-Based Model' Journal of Refugee Studies. 21(1) Pp. 8.

Sherrell, K., J. Hyndman \& F. Preniqi (2005), 'Sharing the Wealth, Spreading the "Burden"? The Settlement of Kosovar Refugees in Smaller British Columbian Cities'. Canadian Ethnic Studies, 37(3). Pp. 76-96.

Simich, L., M. Beiser \& F. Mawani (2002) 'Paved With Good Intentions: Canada's Refugee Destining Policy and paths of Secondary Migration'. Canadian Public Policy. 23(4). Pp. 598607 
Simich, L. (2003). "Negotiating Boundaries of Refugee Resettlement: A Study of Settlement Patterns and Social Support." The Canadian Review of Sociology and Anthropology, 40. Pp. 57591.

Simich, L., M. Beiser \& F. Mawani (2003) 'Social Support and the Significance of Shared Experience in Refugee Migration and Resettlement'. Western Journal of Nursing Research. Pp. $872-891$

Social Research and Demonstration Corporation (SRDC) (2002) 'Best Approaches to Improve the Labour Market Integration of Government Assisted Refugees'. Citizenship and Immigration Canada. http://www.srdc.org/uploads/GAR workshop final report.pdf. February $25^{\text {th }}, 2011$

Stone, W., Gray, M. \& Hughes, J. (2003), "Social Capital at Work", Research Paper No.31, Australian Institute of Family Studies, Melbourne.

Trache, A. M. \& Sweet, R. (2005). 'Exploring the Relationship Between Educational Credentials and the Earnings of Immigrants. 'Canadian Studies in Population, 32 (2) Pp. 177-201.

United Nations High Commissioner for Refugees (1950) 'General Assembly $-5^{\text {th }}$ Session: 428 (V) Statute of the Office of the United Nations High Commissioner for Refugees' Conventions Relating to the Status of Refugees. Pp. 46. http://untreaty.un.org/cod/avl/ha/prsr/prsr.html Retrieved on July 15 th, 2011.

United Nations High Commissioner for Refugees (2010). '2009 - Global Trends: Refugees, Asylum-seekers, Returnees, Internally Displaced and Stateless Persons'. http://www.unher.org/statistics Retrieved on September $15^{\text {th }}, 2010$.

Wald, S \& T. Fang (2008). 'Overeducated Immigrants in the Canadian Labour Market: Evidence from the Workplace and Employee Survey”. Canadian Public Policy, 34(4). Pp. 457-480.

Wahba, J. \& Zenou, Y. (2005), 'Density, social networks and job search methods: theory and application to Egypt'. Journal of Development Economics, 78. Pp. $443-473$.

Watson, C. (2006) 'Integration of Government Assisted Refugees in British Colombia'. Major Research Paper for the Simon Fraser University. http://ir.lib.sfu.ca/retrieve/2835/etd2143.pdf February 20 th, 2011

Wayland, S. V. (2006) 'Unsettled: Legal and Policy Barriers for Newcomers to Canada'. Building Capacity for Social Justice. Community Foundations of Canada \& the Law Commission of Canada (LCC). http://www.communityfoundationsofcanada.ca/documents/legal-policybarriers.pdf Retrieved on June 1st, 2011.

Woolcock, M. (2000) 'The Place of Social Capital in Understanding Social and Economic Outcomes'. http://www.oecd.org/dataoecd/5/13/1824913.pdf Retrieved on June 25th, 2011. 
Xuc, Li. (2008) 'Social Capital and Employment Entry of Recent Immigrants to Canada: Evidence from the Longitudinal Survey of Immigrants to Canada (LSIC)'. Citizenship and Immigration Canada. http://www.cic.gc.ca.libaccess.lib.mcmaster.ca/English/pdf/researchstats/social-capital-w3-eng.pdf Retrieved June 1st, 2011.

Yu, S., E. Ouellet, \& A. Warmington. (2007) 'Refugee Integration in Canada: A Survey of Empirical Evidence and Existing Services'. Refuge. 24(2). Pp. 17-34.

Zictsma, D. (2010). 'Immigrants Working in Regulated Occupations'. CLSRN Working Papers. University of British Columbia. Department of Economics. http://www.statcan.gc.ca/pub/75001-x/2010102/pdf/11121-eng.pdf. March 19th, 2010. 